\title{
Integrated Weed Management Strategies for Sustainable Rice Production in Bangladesh
}

M K A Bhuiyan¹, M U Salam² and M S Kabir ${ }^{3}$

\begin{abstract}
Weed causes huge reduction in crops yield, increases cost of cultivation, reduces input efficiency, interferes with agricultural operations, impairs quality, act as alternate hosts for several insect and diseases .Yield loss due to improper weeding at farmer's field ranged from 4 to $22 \%$ depending on different rice ecosystem in Bangladesh. But at present considering all the cultivable land across the country and other issues; yield loss due to weeds considered about $2 \%$ in a consultation meeting. The present weed control practices in Bangladesh are characterized by intensive use of manual labour, use of herbicide and certain mechanical weeding. Manual weeding, besides laborious is inefficient as it is not done in time in most of the cases and always not practical because of various adverse conditions. Cost effective and integrated weed management system should be adopted to increase economic gain and sustainable rice production. Adopting timely and effectively appropriate weed management techniques we can reduce a significant amount of yield loss and about 0.43 million ton (MT) additional yield could be increased by 2030 . To achieve the target weed management should be done from the very beginning of rice production and up to 30-35 DAP (days after planting) for Aus season, 35-40 DAT (days after transplanting) for T. Aman season and 40-45 DAT for Boro season which indicates critical period of weed infestation in Aus, T. Aman and Boro season. The main approach is that rice field have to keep free from weed up to that days by $2 / 3$ hand weeding (HW) or application of herbicide fb (Followed by) $1 \mathrm{HW}$ or applying weeder fb $1 \mathrm{HW}$ which is called integrated weed management. Herbicide should be applied at proper time and dose which reduce $61 \%$ weeding cost. Mechanical weeding (MW) reduces $50 \%$ weeding cost that keeps environment friendly. Future weed science research specially herbicide efficacy with correct time and dose, new molecule herbicide with low environmental effect, herbicide residues in soil plant system, bioherbicide, allelopathic variety, weed competetive variety, mechanical weeder with related technological developments need a multidimensional approach for ecologically sustainable integrated weed management. Such a system will work toward a socially permissible, environmentally sound, economically feasible, productive and sustainable agricultural system.
\end{abstract}

Key words: Rice weed, Eco- friendly weed management , herbicide

\section{INTRODUCTION}

Weeds reduce rice yield by competing for space, nutrients, light, and water, and by serving as hosts for pests and diseases. Under farmers' conditions, sometimes weed control is not generally done properly or timely, resulting in severe yield reduction. Weeds are recognized as major biological constraints that hinder the attainment of optimal rice productivity in Bangladesh.During peak periods of labour demand, weeding often is done late, causing drastic losses yield in rice. Farm families typically are unable to do all their own weeding and need to hire labor. Two to three HW or MW by BRRI weeder including HW in the plant to plant gap or herbicide application followed by a HW (if needed) are easier, cost-effective and the latest weed management options in rice cultivation in Bangladesh (Bhuiyan et al., 2011; BRRI, 2014). The yield gap was as high as $1 \mathrm{tha}^{-1}$ with $30 \%$ of farmers losing in excess of $500 \mathrm{~kg}$ ha $^{-1}$ (Ahmed et al., 2001) for improper weeding. In direct wet seeded rice about $82 \%$ yield loss occurs if not weeded ( Bhuiyan, 2016). Table 1 presents yield loss percentage due to improper weeding in the farmer's field in Bangladesh which is reportedly 4.25 to $20 \%$ depending on different rice cultures (BRRI, 2006, Bhuiyan et al., 2018). Weeds were reported to cause yield loss of $5 \%$ in commercial agriculture, $10 \%$ in semicommercial agriculture, $20 \%$ in subsistence

1Principal scientific officer, Agronomy Division, Bangladesh Rice Research Institute, Gazipur 1701; ${ }^{2}$ Freelance international Consultant (Agricultural System); ${ }^{3}$ Director General, Bangladesh Rice Research Institute, Gazipur 1701

*Corresponding author's E-mail: bhuiyanbrri@gmail.com (M K A Bhuiyan) 
agriculture in India (Choudhury and Singh, 2015). The contribution of production factors to rice grain yield depends on seasons and ecosystems. Fertilizer largely contributes to rice yield in all the ecosystems followed by weed control. Each rice ecosystem has a critical period of weed infestation. After that grain yield reduces drastically for each day crop weed competition. Weed management strategies diverted from non-chemical weed management to the use of herbicide options for not only increasing its availability and selective effectiveness but also become popular due to shortage of labour and cost-effectiveness. Hence, there is a great need to popularize cost-effective weed management technologies. Though the increased number of herbicides introduced into the market is a reflection of the popularity of the herbicides as a tool for weed management. Systematic studies to assess the impact of improved weed management technologies are required in Bangladesh. Effective weed control requires knowledge of the names, distribution, ecology, and biology of weeds in the ricegrowing regions. No single weed-control measure gives continuous and best weed control in all situations. Various weed control methods including complementary practices, hand weeding, mechanical weeding, chemical weeding, biological control, and integrated approaches are available (De Datta, 1981). These methods need to be fine-tuned for specific regions, ecosystems, cropping systems, and economic groups.

Consequently, there is a great need for a new weed management paradigm in modern agriculture (Bajwa, 2014) based on ecological principles and non conventional weed management approaches. These approaches may offer more durable weed management solutions to lessen problems of herbicide resistance, environmental pollution, weed diversification, weed invasion, and yield losses (Chauhan, 2013; Singh, 2007; Travlos, 2013). Even more, these approaches will facilitate the development of integrated weed management (IWM) strategies which could spearhead the strengthening and broadening of the ecophysiological and evolutionary basis of weed science. The "many little hammers" concept (Liebman and Gallandt, 1997) and the "use of technological advancement" (Young et al., 2017) are two major IWM components that are gaining momentum (Menalled, 2018). As the number of herbicide-resistant weed ecotypes increases and the discovery of new herbicide modes of action (MOAs) declines (Strek, 2014), the need to utilize all available weed management options is crucial.

This study presents a review of modern technologies and approaches and new uses of old technologies and tools suitable for IWM. Following three opinions to be considered for sustainable rice yield; (i) Minimizing rice yield loss by appropriate weeding; (ii) Productivity could be increased by safe use of herbicide; and, (iii) Environmentally and sustainable integrated weed management practices. With the above background, this paper undertook four specific objectives in relation to rice weed management in Bangladesh: (i) Presentation of the changing status of weed management options (ii) Management status of major weeds in rice ecosystem and their dominance ranking (iii) Highlighting the scenarios of yield loss associated with improper weeding; and, (iv) Development and mapping the action plan for three decades on reducing yield loss from the weeds.

\section{MATERIALS AND METHODS}

Yield loss from improper weeding in the farmers' field was determined by performing a group discussion of agronomists, statisticians, and other scientific personnel with the current secondary and reviewed data. It was assumed realistic yield loss from improper weeding in different rice cultures in different agronomic management was about 1.9\% (Kabir et al., 2020). It has been reviewed from different 
experimental data that different weed management practices like hand weeding in improper time, selection of wrong herbicide, herbicide applied in inappropriate time, lacking knowledge of crop weed competition may reduce a certain level of yield. Table 2 presents the baseline yield loss data from different agronomic management (including yield loss from weeds). Action plans for 2021-2030, 20312040, and 2041-2050 for minimizing yield loss due to weeds were developed considering available weed management options. New options like bioherbicide and development of allelopathic variety were also considered. Moreover, the residual effect of herbicide in grain and straw and soil microorganism studies was also taken into consideration.

\section{RESULTS AND DISCUSSION}

\section{Minimizing yield loss by appropriate weeding}

Assessment of crop yield and economic losses due to weeds in rice is an important aspect of this study which helps in formulating appropriate management strategies against weeds. In general, the yield loss due to weeds is almost always caused by a group of different weed species, and these weeds may have substantively different competitive ability (Weaver and Ivany, 1998; Milberg and Hallgren, 2004). Practically, it is very difficult to estimate the yield loss due to single weed species, and therefore, it is estimated as the collective efforts by all the weeds. Most of the studies conducted in the past are more or less based on the experimental data which may not be always representative for field situation. Although estimation of yield losses from the experimental situation is subjected to local effects and sometimes it is valid only for some cropping situation, it may be difficult to extrapolate the results for farmers' yield losses (Milberg and Hallgren, 2004). Further, it is more realistic to establish results from field trials comparing the different treatments in the farmers' field (Walker, 1983; Zanin et al., 1992;
Oerke and Dehne, 1997; Tamado et al., 2002). Yield data of farmers' practice are used to estimate actual yield losses in different crops whereas; yield data of weedy check plot are used to estimate the potential yield loss in relation to weed-free situation. Actual and potential yield losses usually calculate using following formulas as given in Milberg and Hallgren (2004); Galon and Agostinetto (2009); Soltani et al. (2016):

Actual yield loss due to weeds

$=\left(\frac{W F y-F P y}{W F y}\right) \times 100$

Potential yield loss due to weeds

$=\left(\frac{W F y-W C y}{W F y}\right) \times 100$

Where, WFy - crop yield in weed-free situation, FPy - crop yield in farmers' practice, and WCy - crop yield in weedy check plot.

Grain yield losses due to weed competition would be less severe under the transplanting method than those under directseeding. Globally, rice yield losses due to weeds have been estimated at $10 \%$ of total production (Oerke and Dehne, 2004). Table 1 shows yield loss due to improper weeding in different rice cultures in Bangladesh and major rice-growing countries in Asia depending on different rice cultures. Rice yield losses (\%) due to uncontrolled weed growth, improper weeding and weed competition were least $(4.25 \%)$ in transplanted rice (Bhuiyan et al., 2018), although it varies from $40-100 \%$ in direct-seeded rice in Bangladesh. In India, it varies $12-69 \%$ in transplanted rice and $17-98 \%$ in direct-seeded rice. In different countries yield loss (\%) varies depending on different rice cultures and weed management issues. In India, the study revealed that potential yield losses were high in case of direct-seeded rice (15-66\%) and transplanted rice was $13.8 \%$ (Gharde et.al., 2018). It has been estimated that rice yield decreases by $0.75 \mathrm{~kg}$ for every $1 \mathrm{~kg}$ of weed biomass produced (IRRI, 2003). 
Yield loss due to weeds is dependent mainly on the growth of weed biomass. There is a linear relationship between yield loss (\%) and weed infestation. Figure 1 indicates that higher the weed infestation in terms of weed biomass higher the yield loss. It varies from 2$82 \%$ depending on weed control measures in transplanted and direct-seeded rice. Weed biomass (Fig. 1a) was calculated from the model, $y=0.6464 x-3.9319, R^{2}=0.8463^{* *}$ where $Y$ $=\%$ yield loss, $\mathrm{x}=$ weed biomass. The equation showed that the coefficient of weed biomass ( $\mathrm{g}$ $\mathrm{m}^{-2}$ ) is 0.6465 , indicated that increase in every additional biomass we expect a certain $\%$ of yield loss of rice. From the equation estimated weed biomass accumulation was $21.54 \mathrm{~g} \mathrm{~m}^{-2}$ considering $10 \%$ yield loss in direct-seeded rice. In transplanted rice (Fig. 1b) it is estimated an average of $7.44 \mathrm{~g} \mathrm{~m}^{-2}$ weed biomass if considered $10 \%$ yield loss. But we have to reduce yield loss up to a certain level from 2021 to 2030 and beyond gradually. Uncontrolled weed growth occurred the highest weed infestation that caused the highest yield loss. Farmers who control weed but not timely and effectively cause medium weed infestation and yield loss. Where weed infestation is naturally less and weeded timely and accurately poses low weed infestation and minimum yield loss. Need to take necessary measures to reduce weed infestation at a low level by using different weed management tools timely and effectively. In that case, we have to follow integrated weed management options to keep yield loss minimum. In a consultation meeting of BRRI with agronomists, weed scientists and economists considered that national yield loss due to weeds may $1.9 \%$ (Kabir et al., 2020). We projected yield loss will be decrease @ 10\% in each five years with appropriate and proper weeding. Thus yield loss from weeds will be decreased from $1.9 \%$ to $1.33 \%$ in 2030 . As a result yield loss will be minimized and about 0.43 million ton of additional clean rice would be produced.

Table 1. Yield loss due to weeds in rice established by different methods in Bangladesh and major rice-growing Asian countries.

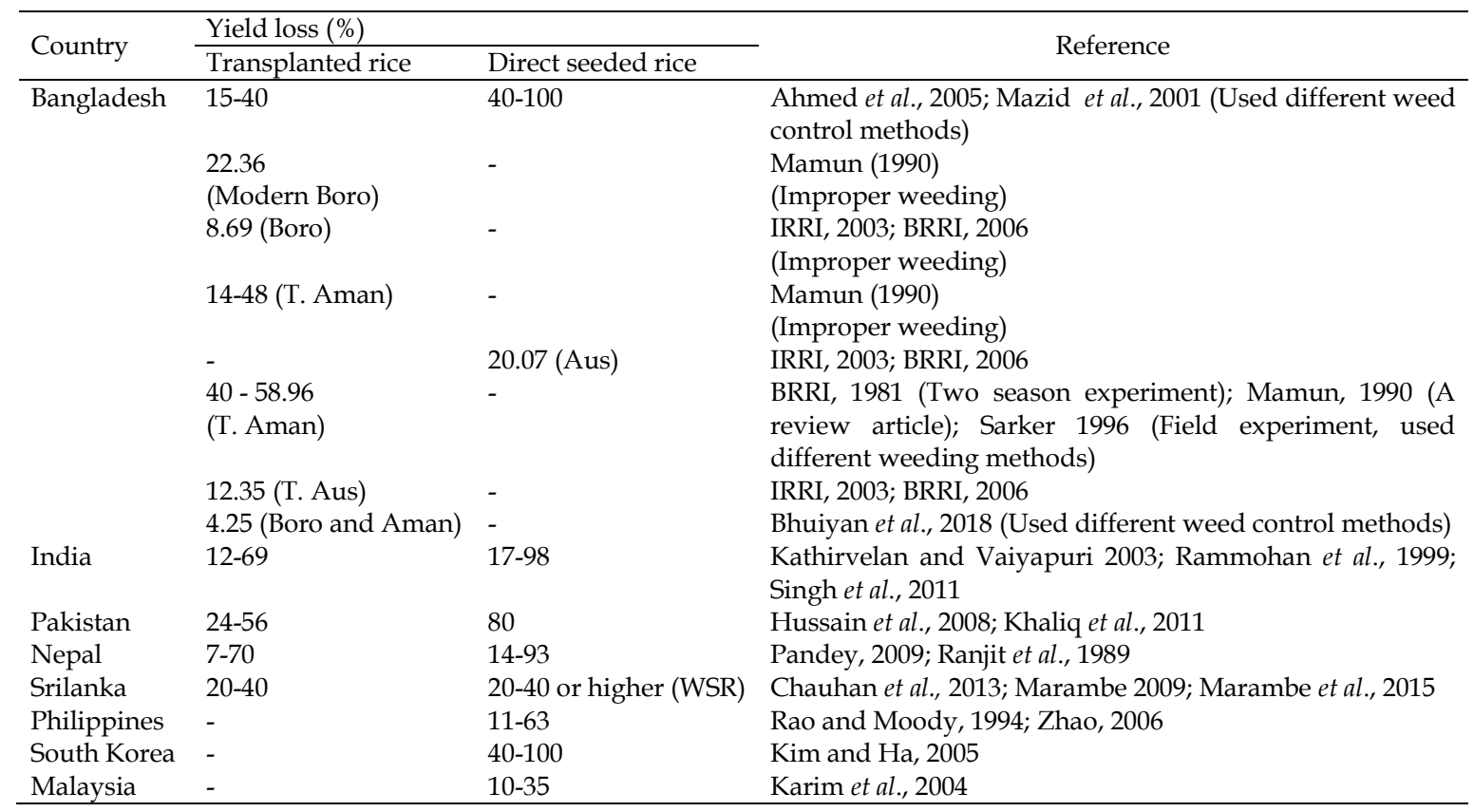




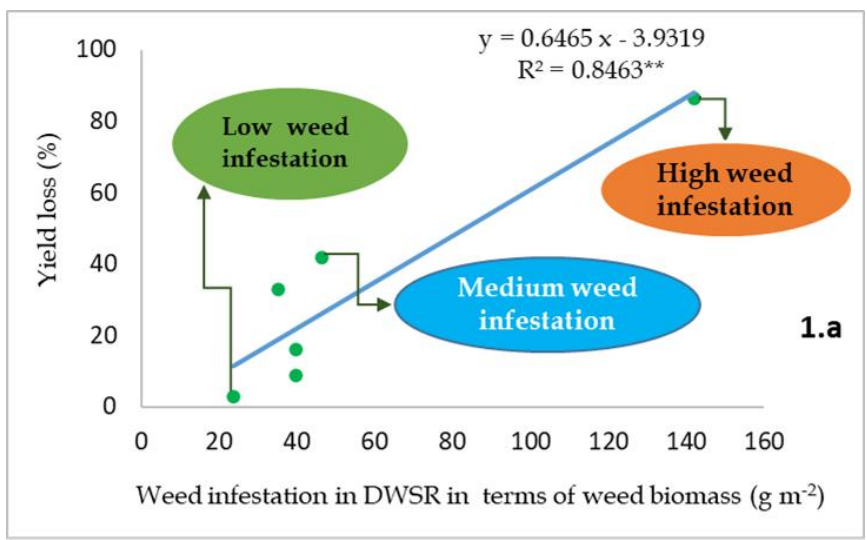

Source: Bhuiyan (2016)

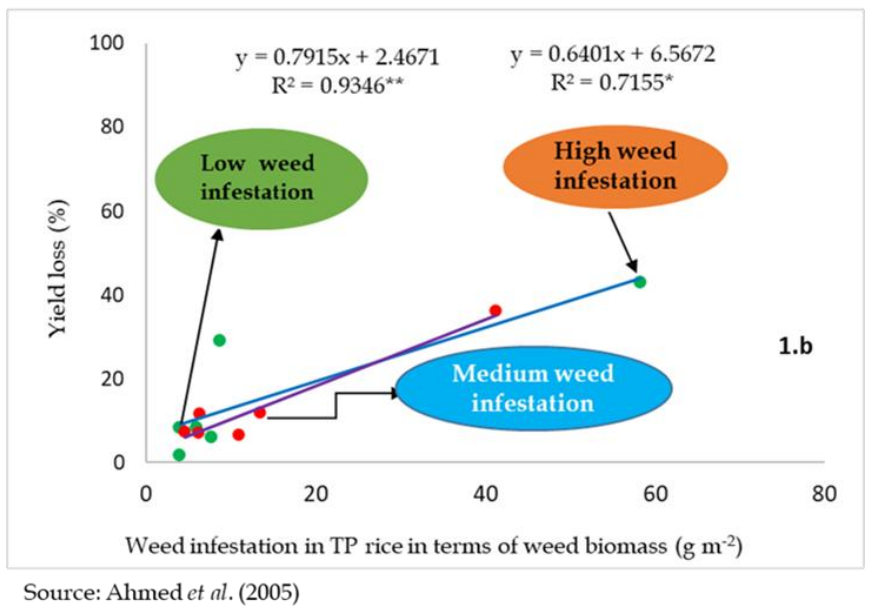

Fig. 1a-1b. Yield loss due to weed infestation in transplanted and direct-seeded condition.

Table 2. Yield loss (\%) due to different agronomic factors.

\begin{tabular}{ll}
\hline Agronomic factor & Yield loss (\%) \\
\hline Time of sowing/transplanting & 4.75 \\
Seedling age & 2.50 \\
Spacing & 1.20 \\
Weeds & $\mathbf{1 . 9 0}$ \\
Fertilizer (dose and timing) & 4.00 \\
Other agronomy management (seed quality, tillage etc) & 1.00 \\
Total & 15.35 \\
\hline
\end{tabular}

Source: Adopted from Kabir et al., 2020

\section{When to weeding to overcome yield loss?}

The climate of Bangladesh is hot and humid which favours weeds to germinate vigoursely. Weeds commonly found in Bangladesh about 350 species are recorded in Asian countries, these weeds cause roughly $33 \%$ of total crop loss in different crops (CIMMYT, 2011). The number of species and density of weed in an area depends on the land use pattern, associated crops, and its ecological conditions. Among the weed species commonly found, about one-third of plants are monocotyledonous and the remaining plants are dicotyledonous. There are many weed 
grows in the rice field of Bangladesh. From which Tables 3 and 4 list nine harmful ${ }^{1}$ weeds in lowland rice and ten harmful weeds in upland rice (BRRI, 2006).

Table 3. List of nine major harmful weeds of lowland in Bangladesh.

\begin{tabular}{lll}
\hline Common name & Scientific name & Group \\
\hline Shama & Echinochloa crus-galli & Grass \\
Gaicha & Paspalum disticum & Grass \\
Halde mutha & Cyperus difformis & Sedge \\
Bara chucha & Cyperus iria & Sedge \\
Bara javani & Fimbristylis miliacea & Sedge \\
Chechra & Scripus maritimus & Sedge \\
Pani kachu & Monochoria vaginalis & Broad leaf \\
Jhil marich & Sphenochlea zeylanica & Broad leaf \\
Pani long & Ludwigia octovalvis & Broad leaf \\
\hline
\end{tabular}

*Photograph of weeds have been listed in appendix $1 \mathrm{a}$

Table 4. List of ten major harmful upland weeds in rice field.

\begin{tabular}{lll}
\hline Common name & Scientific name & Group \\
\hline Khudey shama & Echinochloa colona & Grass \\
Durba & Cynodon dactylon & Grass \\
Ulu & Imperata cylindrica & Grass \\
Chapra & Elusine indica & Grass \\
Kakpaya grass & Dactyloctenium aegyptium & Grass \\
Anguli grass & Digitaria sanguinalis & Grass \\
Mutha & Cyperus rotundus & Sedge \\
Kesuti & Eclipta allba & Broad leaf \\
Kata notey & Amaranthus spinosus & Broad leaf \\
Kanainala & Commelina diffusa & Broad leaf \\
\hline
\end{tabular}

*Photograph of weeds have been listed in appendix $1 \mathrm{~b}$

The summed dominance ratio (SDR) is more informative than any single measure in reflecting the contribution of a species in the community. It indicates the most harmful and dominating weed species grown in a crop field. Table 3 and 4 indicate topmost harmful weeds in lowland and upland conditions found in Bangladesh. Based on harmful effect, dominance, and aggressivity. Some dominating weeds were identified in transplanting and direct seed rice in Table 5. The most dominant weed species were arranged in the order of Echinochloa crus-galli > Scirpus

\footnotetext{
${ }^{1} \mathrm{~A}$ harmful weed is a weed that has been designated by an agricultural or other governing authority as a plant that is injurious to agricultural or horticultural crops, natural habitats or ecosystems, or humans or livestock.
}

juncoides > Cynodon dactylon > Monochoria vaginalis> Cyperus iria> Cyperus difformis> Sphenoclea zeylanica >Fimbristylis miliacea. In different agricultural regions, it almost originates similar with little variations on different ecosystems.

Table 6 shows a critical period of weed infestation in Aus, Aman, and Boro seasons. The main principle is that we have to keep rice weedfree up to that time by $2 / 3 \mathrm{HW}$ (hand weeding) or application of herbicide fb (Followed by) 1HW or applying weeder $\mathrm{fb} 1 \mathrm{HW}$. We have to prevent competition of weed and rice. These techniques involved integrated weed management. Not a single method is enough to control weeds in time properly. Integrated weed management could be followed for minimizing yield loss due to improper weeding (Table 7). Farmers can follow hand weeding, weeder, or herbicide whatever they choose. However, weed management should be done from the very beginning of rice production and specific stage of the rice life cycle.

\section{Different weed management options}

\section{During land preparation}

- Weed control during land preparation is crucial to reduce the amount of weed pressure in the field.

- Land preparation should start at least 7-10 days before planting. Plowing destroys weeds and remaining stubbles from the previous crop.

- Weeds should be allowed to grow before the next cultivation. In addition, the proper leveling of field helps to retain a constant water level that controls weeds.

\section{Weed control in the nursery}

- Land should be prepared two weeks before seeding.

- If there are weed seedlings in the nursery bed, separate them from rice seedlings during pulling and bundling to avoid planting weeds. 
Table 5. Weed dominance ranking (most harmful weeds) in rice cultivation.

\begin{tabular}{|c|c|c|}
\hline Dominance ranking & Weed & Reference \\
\hline & Transplanted rice & \multirow{7}{*}{ Bhuiyan et el., 2017} \\
\hline 1 & Echinochloa crus - galli & \\
\hline 2 & Scirpus juncoides & \\
\hline 3 & Cynodon dactylon & \\
\hline 4 & Cyperus difformis & \\
\hline 5 & Marsilea minuta & \\
\hline 6 & Monochoria vaginalis & \\
\hline & Transplanted rice & \multirow{9}{*}{ Mahbub and Bhuiyan, 2019} \\
\hline 1 & Cyperus difformis & \\
\hline 2 & Echinochloa crus - galli & \\
\hline 3 & Scirpus juncoides & \\
\hline 4 & Monochoria vaginalis & \\
\hline 5 & Marsilea minuta & \\
\hline 6 & Cynodon dactylon & \\
\hline 7 & Sphenoclea zeylanica & \\
\hline 8 & Eclipta alba & \\
\hline & Direct seeded rice & \multirow{13}{*}{ Bhuiyan, 2016} \\
\hline 1 & Scirpus juncoides & \\
\hline 2 & Echinochloa crus - galli & \\
\hline 3 & Cynodon dactylon & \\
\hline 4 & Cyperus iria & \\
\hline 5 & Cyperus difformis & \\
\hline 6 & Sphenoclea zeylanica & \\
\hline 7 & Monochoria vaginalis & \\
\hline 8 & Marsilea minuta & \\
\hline 9 & Lindernia floribanda & \\
\hline 10 & Leptochloa chinensis & \\
\hline 11 & Ludwigia octovalvis & \\
\hline 12 & Fimbristylis miliacea & \\
\hline & Transplanted rice & \multirow{12}{*}{ Islam et al., 2017} \\
\hline 1 & Echinochloa crus - galli & \\
\hline 2 & Scirpus juncoides & \\
\hline 3 & Monochoria vaginalis & \\
\hline 4 & Cyperus iria & \\
\hline 5 & Digitaria sanguinalis & \\
\hline 6 & Leersia hexandra & \\
\hline 7 & Panicum repens & \\
\hline 8 & Cyperus difformis & \\
\hline 9 & Nymphaea nouchali & \\
\hline 10 & Marsilea quadrifolia & \\
\hline 11 & Fimbristylis miliacea & \\
\hline
\end{tabular}

Table 6. Critical period of weed infestation in rice culture.

\begin{tabular}{lcc}
\hline \multirow{2}{*}{ Season } & \multicolumn{2}{c}{ Critical period (day) of weed infestation in rice } \\
\cline { 2 - 3 } & Direct seeded rice (DAS) & Transplanted rice (DAT) \\
\hline Aus & $30-35$ & $30-35$ \\
Aman & $45-50$ & $35-40$ \\
Boro & $55-75$ & $40-45$ \\
\hline
\end{tabular}


Table 7. Integrated weed management to reduce rice yield loss due to weed infestation.

\begin{tabular}{lll}
\hline Cultural management & Mechanical control & Chemical control \\
\hline $\begin{array}{l}\text { - Use weed-free seed } \\
\text { - Proper land preparation and practice stale } \\
\text { seedbed technique }\end{array}$ & $\begin{array}{c}\text { BRRI weeder (15 DAT) }+ \\
\text { 1 HW in 30-35 DAT } \\
\text { - Water management }\end{array}$ & $\begin{array}{l}\text { Power operated weeder Pre/post-emergence herbicide } \\
\text { - Herbicide fb 1HW (35-45 DAT) }\end{array}$ \\
$\begin{array}{l}\text { - Manual weeding 2-3 times as needed. To avoid } \\
\text { competition weed during 15, 30 and 45 DAT }\end{array}$ & & $\begin{array}{l}\text { herbicide(s) with right time, right } \\
\text { dose, right method and with } \\
\text { proper protection }\end{array}$ \\
\hline
\end{tabular}

Source: Bhuiyan et al., 2018

\section{Weed control during early growth stage}

Weed control is critical after planting until the rice canopy is fully covered. Control methods vary depending on the rice ecosystem and planting method.

\section{Weed control in transplanted rice}

- Apply pre-emergence herbicide (e.g., pretilachlor or butachlor or bensulfuron methyl + acetachlor) fb 1HW if needed.

- If grass weeds are the main weed problem, apply early post-emergence herbicide (e.g., pyrazosulfuron ethyl, ethoxysulfuron, phenoxlum etc.) fb $1 \mathrm{HW}$ if needed.

- Do not allow soil surface to dry after transplanting. Keep the soil moist to saturated. Dry soil reduces the performance of pre-emergence herbicides.

- If herbicides have not been applied, or if weeds are emerging, it is required to use BRRI weeder to control weed seedlings that are at 3-4 leaf stages.

- In case of hand weeding it should be done properly at 15-18 DAT( $1^{\text {st }}$ weeding), 30-35 $\operatorname{DAT}\left(2^{\text {nd }}\right.$ weeding) and at $40-45 \operatorname{DAT}\left(3^{\text {nd }}\right.$ weeding) besides timely until rice is fully covered by a canopy.If weed competetion is low then weeding twice at 15-18 DAT and at 40-45 DAT.

- Rice crops must be kept weed-free by any method up to 30-45 DAT to get optimum yield.

Weed control indirect wet seeded rice by broadcasting/drum seeding

- Apply pre-emergence herbicide (e.g., pretilachlor + fenclorim 2-3 DAS or post- emergence e.g. Pyrazosulfuron ethyl at 1012 DAS).

- For post-emergence herbicide application, drain water in the field to expose weeds, then spray herbicide. (Note: Post-emergence herbicide should come in contact with leaves of weeds to be absorbed by the weeds. When weeds are submerged in water, post-emergence will not be effective).

- Do not allow the soil surface to dry after seeding. Flush irrigate as needed to keep the soil moist to saturated. A dried soil surface will reduce the performance of preemergence herbicides.

- If herbicides have not been applied, or if weeds are emerging, may use BRRI weeder in a row-seeded crop to control weed seedlings that are at 3-4 leaf stages.

- Irrigate one day later to prevent buried and uprooted weeds from recovering.

- Hand weed as needed until rice canopy is covered.

\section{Weed control in dry seeded rice}

- A weed-free field is essential for early vigour in a dry-seeded rice crop. Be sure to follow steps for weed control during land preparation to avoid yield loss to weeds.

- Apply pre-emergence herbicide (e.g., oxadiazon, pendimethalin or oxadiargyl ) in moist soil during 2-3 DAS. If the seed is sown on dry soil, flush irrigate the field first then spray the herbicide. Pendimethalin works well in dry soil. 
- Post-emergence herbicides like Bispyribac sodium SC or penoxulam 240SC could be used at $20 \mathrm{DAE}$.

- If herbicide is not used to control weeds, hand weeding is required to control weed pressure.

\section{Cultural Management for weed control}

Cultural weed control includes non-chemical crop management practices ranging from variety selection to land preparation to harvesting and postharvest seed processing. Cultural weed control is a part of integrated weed management which involves the integrated use of cultural, manual, and/or mechanical control methods. It is easy to practice, acceptable, and accessible to small and large farmers as well as non-chemical and ecologically sound.

\section{How to use cultural practices to control weeds?}

- Timing. Weeds need to be controlled from planting until the rice canopy closes.

- Land preparation and leveling. Use land preparation to control growing weeds and to allow weed seeds to germinate. Kill newly emerging weeds by repeating tillage at adequate intervals.

- Reduce weed entry into fields. Prevent the introduction of weeds into fields by: i) using clean good quality seed, ii) keeping seedling nurseries free of weeds to make sure weeds are not planted with the rice seedlings, iii) keeping irrigation channels and field bunds free of weeds to prevent weed seeds or vegetative parts entering the fields iv) using clean equipment to prevent field/crop contamination and v) rotate crops to break weed cycles.

- Fallow management. Destroy weeds in fallow fields (e.g., use tillage) to prevent flowering, seed-set and the build-up of weed seeds in the soil (Should remember: "one year of seeds, seven years of weeds").

- Crop-weed competition. Select a weedcompetitive variety with early seedling vigor, and high tillering to suppress weeds. Transplanted crops tend to have fewer weeds and less yield loss than direct-seeded crops. Transplant healthy, vigorous seedlings that can better compete with weeds in the early stages. Maintain an adequate plant population that closes its canopy by maximum tillering to shade out weeds. Apply Nitrogen (N) fertilizer just after weeding to minimize rice-weed competition for $\mathrm{N}$.

- Water management. Water is the best control for weeds. Many weeds cannot germinate or grow under flooded conditions (e.g. most grasses and some sedges). Flooding is effective against many weed species but some species such as Sphenochloa zeylanica, Monochoria vaginalis and Cyperus difformis are not controlled by flooding.Maintain a $2-5 \mathrm{~cm}$ water level in the field to minimize weed emergence and lower weed pressure. If water is sufficient, fields can be continuously flooded from the time of transplanting to when the crop canopy covers the soil completely.

\section{Mechanical weed control}

Mechanical weeding is a part of integrated weed management that refers to the integrated use of cultural, manual, mechanical and/or chemical control methods. Mechanical weeding is preferable because it is nonchemical and ecologically sound, less labour needed and costs less than hand weeding and less drudgery than in hand weeding. BRRI power weeder (BPW) and BRRI weeder (BW) reduced weeding cost, enhanced weed control and improved the labour efficiency without sacrificing grain yield with the highest $\mathrm{BCR}$ obtained in BPW (1.22) followed by BW (1.16) 
and HW (1.11). BPW and BW appeared to be economic, easy and also environmentally safe weed control devices in low land rice cultivation (Islam et al., 2017). But they have some limitations of mechanical weeding, such as:

- Only suitable for row-planted crops.

- Difficult in hardened soil or where water is limited.

- Difficult to remove weeds within crop rows.

- $\quad$ Only effective with young weeds (2- to 4 leaf stage).

\section{How to apply mechanical weeder effectively?}

- With 2-3 cm of water in the field, start using a weeder when emerged weeds are young (3 to 4 leaf stage).

- $\quad$ Remove the weeds near the plants by hand.

- Ten decimal lands could be weeding by one hour with one man.
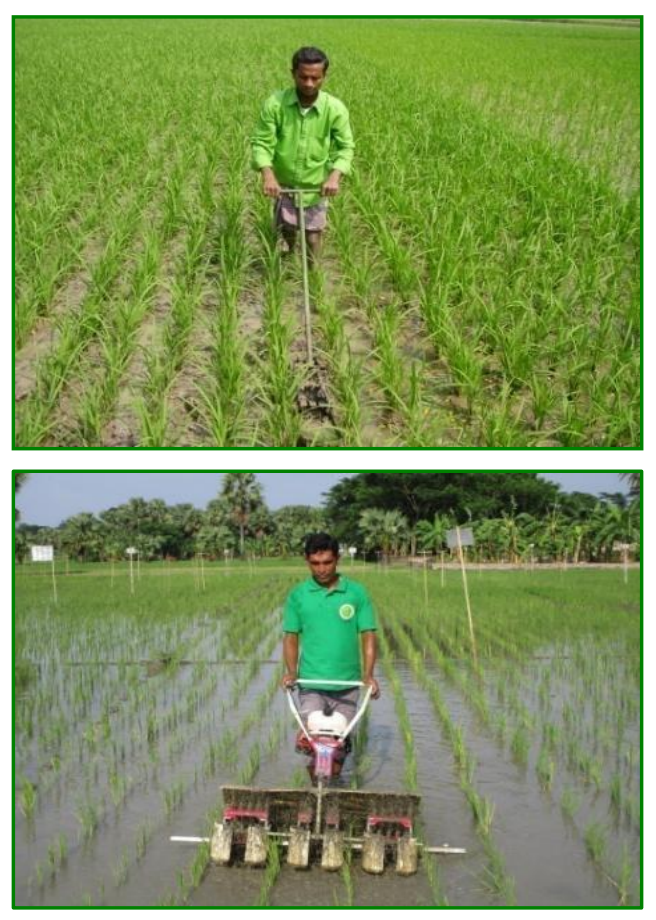

Mechanical weeding

\section{Manual weed control}

Manual weeding is preferable because it is non-chemical; ecologically sound, Provides clean and thorough weeding, and good for resource-poor farmers where labor is available at low wages.

\section{Limitations of hand weeding}

- Labour-intensive, time-consuming and costly and high drudgery with stress on labour.

- Difficult if the soil surface is not moist and loose.

- Difficulty in identifying and removing certain grassy weeds at early stages (e.g. weedy rice, Echinochloa spp.). Have to remove such weeds from the field at flowering time.

- Weeds may survive if pulled and dropped into standing water.

Hand weeding: How to do it effectively and timely

- Weeds need to be controlled from planting until the crop canopy closes.

- Start hand weeding within 15 days of planting (or when weeds are large enough to grasp).

- $\quad$ Repeat the weeding once or twice more at 30-35 and 40-50 days after transplanting (DAT) or 40-45 and 55-75 days after sowing (DAS).

- Do not allow weeds to flower and set seeds in a crop field.

- Use good land leveling to reduce weeds.

\section{Chemical weed control}

In chemical weed control, chemicals called herbicides are used to kill certain plants or inhibit their growth.Chemical weed control is an option in integrated weed management that refers to the integrated use of cultural, manual, mechanical and/or chemical control methods. 


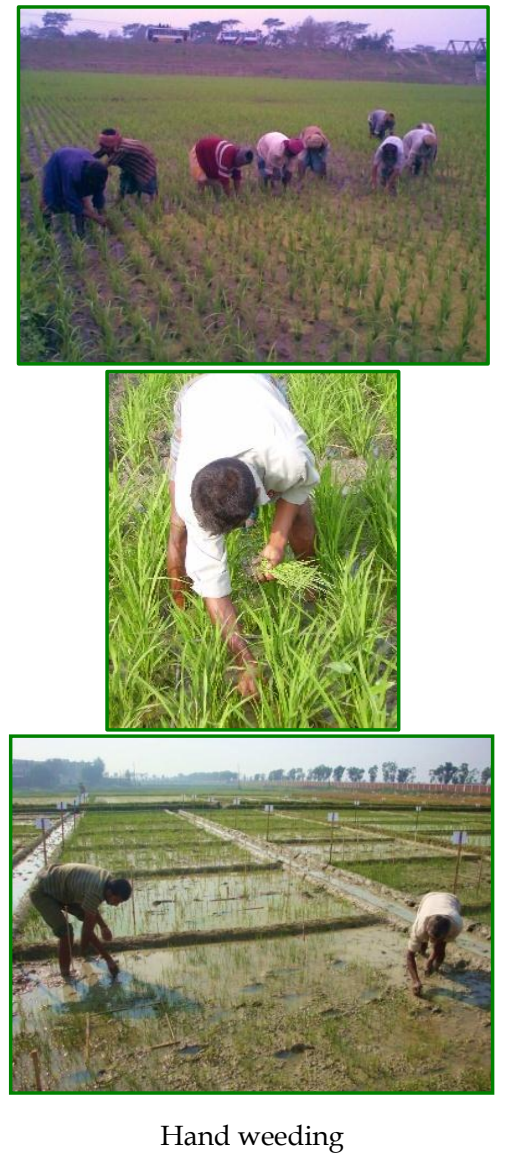

Classification of herbicide

Based on time of application, herbicides are classified as

- Preplant. Preplant herbicides are applied before the crop is planted. They are usually used to kill weeds that have germinated before planting or were left from fallowing. Glyphosate and paraquat is the example of a pre-plant herbicide. glyphosate or paraquat could be use to kill fallow weeds before 8-10 DAT of rice. Only selective herbicide surfentrazone can be used as pre plant herbicide before $2 / 3$ days of transplanting.

- Preemergence. Applied after the crop has been planted but before weeds emerge. Preemergence herbicides are usually applied to the soil surface. They are used to prevent the establishment of weeds right after planting. They must not be toxic to the crop. Butachlor, pretilachlor, mefeneset + bensulfuron methyl, bensulfuron methyl+ acetachlor is the example of a pre-emergence herbicide.

- Postemergence. Applied after weeds have emerged. Post-emergence herbicides are used to control weeds that have been established in the crop. They should not be toxic to the crop and usually must contact the weed foliage to be more effective. An example of a post emergence herbicide is pyrozosulfuron ethyl, ethoxysulfuron, diafimoni, bensulfuron methyl+ quinchlor, bispyribac sodium SC, penoxulam 240 SC etc.

\section{Based on mode of action, herbicides are classified into two}

- Contact. Contact herbicides are applied to foliage and other above-ground parts of a plant. They kill plant tissues at or very close to the application site. An example of a contact herbicides are propanil, glyphosate, 2,4-dichlorophenoxyacetic acid (2,4-D)

- Translocated/Systemic. Translocated herbicides are absorbed by the roots or above-ground parts of a plant. Within the plant, the herbicides then move to and kill tissues that may be remote from the point of application but where herbicide action occurs.Translocated herbicide move to the site of action via the transport mechanisms within the plant; the xylem and phloem. The xylem transports water and nutrients from the soil to growth sites and the phloem transports products of photosynthesis (for instance, sugars) to growth and storage sites.

\section{Based on selectivity}

Selectivity is how narrowly or widely an herbicide is effective on plants and falls into two categories: 
- Selective. A herbicide that kills or stunts some plant species with little or no injury to others, especially the crop, is selective. Examples of selective herbicides used in rice production are butachlor, propanil,bensulfuron methyl+acetachlor, ethoxysulfuron and 2,4-D. These herbicides do not kill rice and are therefore safe to use.

- Non-selective. A herbicide that kills all plant species, or shows no selectivity, is nonselective. An example of a nonselective herbicide is glyphosate and paraquat that kills all plants in a field, including rice.

How to use herbicides effectively to control weeds?

- Always read and follow the instructions on the product label.

- Ensure the product is suited for the type and stage of crop and weeds to be controlled.

- Ensure field conditions are suitable (e.g., some products only work when the soil is moist, or when there is standing water or no standing water).

- Products are designed for early application when weed control is most important. Some products are designed to control the weeds before they emerge (preemergence), while others are only effective after the weeds have emerged (postemergence).

- Use the recommended rate of fresh and clean water.

- Uniformly apply herbicide across the field.

- Spray herbicide from a height of around 50 $\mathrm{cm}$ above the target.

- Minimize movement of the herbicide to non-target areas by using low pressures, avoiding applications in very strong winds, and by limiting water run-off from fields.

- Spray perpendicular across the wind, so that product is blown away from the applicator.

- Be sure to rotate the usage of herbicides so weeds do not develop resistance.

\section{Limitations of chemical weed control}

- Herbicides are toxic substances, if those are used unwisely or incorrectly can cause health and environmental problems.

- Herbicides are often weed-specific.

- Weeds can develop herbicide resistant if farmers are too reliant on one type of herbicide.

- Drift risk to neighbor crops.

- Applicators require skills in application and calibration.

\section{Safety consideration}

- Always wear protective equipment. Use appropriate cover for head, eyes, nose, mouth, and hands. Wear long-sleeved shirts, long pants, and covered footwear.

- When mixing the product, always stand upwind and wear protective clothing especially face protection.

- Wash contaminated clothes separately from other household clothes.

\section{Note}

- At recommended doses, a herbicide may be selective when used with a particular crop.

- However, if higher doses are used or if the herbicide is applied at the wrong time, it can damage or even kill the crop.

- The same herbicide may be selective or nonselective, depending on the rate and time of application. 


\section{Residual effect of herbicide}

According to World health organization (WHO) "any substance or mixture of substances in food for man or animals resulting from the use of a pesticide and includes any specified derivatives, such as degradation and conversion products, metabolites, reaction products, and impurities that are considered to be of toxicological significance" are defined as herbicide/ pesticide residues.

Herbicide is gaining popularity in rice cultivation due to its low cost, high efficacy, and timely control of weeds. In Bangladesh, the annual consumption of herbicides grew over 7400 metric tons in 2019 (BCPA, 2020) compared to only 108 tons during 1986-87 (BBS, 1991), and the growth is almost exponential (Fig. 3). Pyrazosulfuron ethyl, mefeneset+ bensulfuran methyl, mefeneset + acetochlor, bispyribac sodium, oxadiazone, pretilachlor, butachlor, ethoxysulfuran, oxadiarzil, 2,4-D, etc. are the commonly used herbicides in rice cultivation in Bangladesh (Table 8). Data indicated that the use of herbicide will be considerably increased in near future for rice cultivation. Incorrect and indiscriminate application of herbicides affects negatively the health of humans, plants and animals. Particularly hazardous are the poorly degradable herbicides whose persistence may lead to long-term accumulation.

Soil microorganisms are an important link in the soil-plant system. Herbicides can contaminate soil, water, turf, and other vegetation. Insecticides are generally the most acutely toxic class of pesticides, but herbicides can also pose risks to non-target organisms. Herbicide sometimes contaminates the surface and groundwater. Some herbicides show phytotoxicity to the rice plant. Moreover, the question arises frequently from different corners, especially from the environmentalists about the effect of herbicide on the environment along with soil and water. The policymakers also want to know its safe use and residual influence on soil and crop. Some herbicides may take a long time to disintegrate, may adversely affect the soil health and groundwater. Herbicide residue may persist in straw and grain. Although herbicide is less toxic than insecticides, even the information regarding its persistence in soil and crop plant is lacking in Bangladesh.But studied from India demonastred that at harvest, herbicides in various commodities and different families were found either below the maximum residue limit or below detectable limits in grain and straw (Sondhia ,2014). Herbicide residues after recommended use for control of weeds are relatively high initially; however, the levels are reduced rapidly, and residues are often not detectable after a few days or weeks or at harvest (Sondhia ,2014). Nevertheless,Farmers should be informed about the influence of herbicides on the soil and crop. Furthermore, herbicide residue persistence on soil and crop if any needs to be carefully studied in Bangladesh condition.

Microbiological effects of herbicides were studied at BRRI (BRRI, 2015-16). Higher concentrations of herbicide treatments resulted in much lower microbial counts compared to soils treated with recommended herbicide dose. But in general, all bacterial and fungal populations were reduced three days after herbicide application (DAHA) and the population increased 7-20 DAHA and thereafter microbial population fluctuated over time. So the application of herbicide in soil reduced soil microorganisms in a certain time and after 7-20 days, it becomes increased than before.

Therefore, we need clear understanding of herbicide residue in soil and crop plants for safe food grain consumption. As the SDG 2 and BDP (Bangladesh Delta Plan) 2100, Volume 4 baseline study indicated, we have to produce and ensured safe food and nutrition. 
Table 8. The herbicide used in Bangladesh are listed with chemical/common name and effective dose with remarks.

\begin{tabular}{|c|c|c|c|}
\hline Chemical & $\begin{array}{l}\text { Effective } \\
\text { dose/ha }\end{array}$ & $\begin{array}{l}\text { Time of } \\
\text { application }\end{array}$ & Remark \\
\hline Oxadiazon & $\begin{array}{l}1.0 \mathrm{~L} \\
(\mathrm{DSR}) \\
2.0 \mathrm{~L} \\
(\mathrm{TPR})\end{array}$ & 3-5 DAS/DAT & $\begin{array}{l}\text { Direct dry/wet seeded and transplanted rice. } \\
\text { Effective for sedges, broadleaves and some grasses. Works } \\
\text { best with standing water or at least moist soil. Soil must } \\
\text { remain moist after application to maintain activity. }\end{array}$ \\
\hline Butachlor & $25 \mathrm{~kg}$ & 3-5 DAT & $\begin{array}{l}\text { Pre-emergence, effective for grasses, some broadleaves } \\
\text { and sedges }\end{array}$ \\
\hline Carfentrazone ethyl & $62.5 \mathrm{~g}$ & 20-22 DAT & Post emergence, effective for broadleaf \\
\hline Pretilachlor & $1.0 \mathrm{~L}$ & 3-5 DAT & $\begin{array}{l}\text { Pre-emergence, effective for grasses, some broadleaves } \\
\text { and sedges }\end{array}$ \\
\hline Pretilachlor+safener & $1.0 \mathrm{~L}$ & 3-5 DAS/DAT & DSR, effective for grass, sedge and broadleaves \\
\hline Pyrazosulfuron ethyl & $125-150 \mathrm{~g}$ & 10-12 DAS/DAT & Early post-emergence, sedges and broadleaves, few grasses \\
\hline Ethoxysulfuran & $100 \mathrm{~g}$ & 10-12 DAS/DAT & Early post-emergence.Effective for sedges and broadleaves \\
\hline Glyphosate & $4-5 \mathrm{~L}$ & Pre plant & $\begin{array}{l}\text { Pre-plant, deep-rooted perennial weeds and annual } \\
\text { grasses, sedges, and broadleaves. }\end{array}$ \\
\hline Paraquate & $2.0 \mathrm{~L}$ & Pre-plant & Pre-plant, suppress weed dry mass. \\
\hline MCPA & $1.0 \mathrm{~L}$ & 25-28 DAT & Post emergence, effective for wide ranges of weed \\
\hline Oxadiarzyl & $188 \mathrm{ml}$ & 3-5 DAS/DAT & $\begin{array}{l}\text { Preemergence, effective for dry and wet seeded rice. Spray } \\
\text { without standing water in the field. }\end{array}$ \\
\hline 2,4 D - Amine & $1125 \mathrm{~g}$ & 20-25 DAS/DAT & $\begin{array}{l}\text { Post-emergence, effective for broadleaves and annual } \\
\text { sedges. Weeds need to be above the waterline. }\end{array}$ \\
\hline 2,4 D butyl ester & $1.8 \mathrm{~kg}$ & 20-25 DAS/DAT & $\begin{array}{l}\text { Post-emergence, effective for broadleaves and annual } \\
\text { sedges. Weeds need to be above the water line. }\end{array}$ \\
\hline $2,4 \mathrm{D}$ & & & Pre-plant \\
\hline Pendamethalin & $2.0 \mathrm{~L}$ & 3-5 DAS/DAT & $\begin{array}{l}\text { Preemergence, effective for dry seeded rice. Effective for } \\
\text { Echinochloa spp., some annual grasses, sedges, and } \\
\text { broadleaves. Need residual moisture for activating. }\end{array}$ \\
\hline Mefenacet+Bensulfuron methyl & $1111 \mathrm{~g}$ & 3-5 DAT & Pre emergence, effective for all weeds \\
\hline $\begin{array}{l}\text { Bensulfuron methyl + } \\
\text { Acetachlor }\end{array}$ & $750 \mathrm{~g}$ & 3-5 DAT & Pre emergence, effective for all weeds \\
\hline Butachlor+Propernil & $1.0 \mathrm{~L}$ & 3-12 DAS/DAT & $\begin{array}{l}\text { Pre and post-emergence, effective for sedge and } \\
\text { broadleaves, some grasses. Apply on saturated soil, flood } \\
\text { field 1-3 DAA; spray volume is } 200 \mathrm{~L} / \text { ha }\end{array}$ \\
\hline $\begin{array}{l}\text { Pyrazosulfuron } \\
\text { ethyl+pretilachlor }\end{array}$ & $800 \mathrm{~g}$ & 3-15 DAT & $\begin{array}{l}\text { Pre and post-emergence, effective for sedge and } \\
\text { broadleaves, some grasses }\end{array}$ \\
\hline Bispyrabyc Sodium & $125-150 \mathrm{~g}$ & 8-16 DAS/ DAT & $\begin{array}{l}\text { Post-emergence, effective for grasses (especially Shama) } \\
\text { some BL and S. Drain excess water before spraying for } \\
\text { target weeds to appear one-half part over the water } \\
\text { surface and re-irrigate during 1-3 DAA. }\end{array}$ \\
\hline Oxylfluorfen & $1.0 \mathrm{~L}$ & 3-5 DAT & Pre emergence \\
\hline $\begin{array}{l}\text { Bensulfuron } \\
\text { methyl+queenchlore }\end{array}$ & $600 \mathrm{~g}$ & 3-15 DAT & Pre and post emergence \\
\hline Acetachlor & $250 \mathrm{ml}$ & 3-5 DAT & Pre emergence \\
\hline Cylophop-butyle & $100 \mathrm{ml}$ & 15 DAT & Post emergence, only annual grasses \\
\hline $\begin{array}{l}\text { Bispyribac } \\
\text { sodium+bensulfuron methyl }\end{array}$ & $142.5 \mathrm{~g}$ & 10-12 DAT & Post emergence; grass, sedge and broadleaves \\
\hline $\begin{array}{l}\text { Bensulfuron methyl } \\
10 \%+\text { Chlorimuron ethyl 10\% }\end{array}$ & $20 \mathrm{~g}$ & 12-15 DAT & Post emergence; grass, sedge and broadleaves \\
\hline $\begin{array}{l}\text { Metolachlor+ Bensulfuron } \\
\text { methyl } 20 \%\end{array}$ & $190 \mathrm{ml}$ & 3-6 DAT & Pre emergence, grass, sedge and broadleaves \\
\hline Sulfentrazone 48SC & $200 \mathrm{ml}$ & $\begin{array}{l}\text { Before } 3 \text { days of } \\
\text { TP and upto 3DAT }\end{array}$ & Pre plant and pre emergence herbicide \\
\hline Fenxo-prop-P- ethyl & $500 \mathrm{ml}$ & 3-5 DAT & Pre emergence, grasses \\
\hline Diafimoni 200SC & $190 \mathrm{ml}$ & $\begin{array}{l}\text { 12-15 DAT } \\
\text { (1-3 leaves) }\end{array}$ & Post emergence; all weeds \\
\hline
\end{tabular}


Productivity could be increased using herbicides

Due to shortage of labour in peak period and the higher cost of hand weeding, herbicide use is increasing every year in Bangladesh. The trend of herbicide use (BCPA, 2019) up to 2018 (Fig. 2) indicates that in the future herbicide use will increase sharply and labour productivity will also be increased. Research in Bangladesh demonstrated that herbicide applications would produce similar rice yields to three carefully timed hand weeding with a significant reduction in labour requirements and total costs. Pre-emergence herbicides are $38-46 \%$ cheaper than one hand weeding (Mazid et al., 2001).

Economic analysis of rice production in Bangladesh revealed that the net income from herbicide application was 116\% higher than three times hand weeding (Rashid, 2012). Herbicide use reduced weed control time to a mean of 84 hours ha ${ }^{-1}$ compared to 590 hours ha ${ }^{-1}$ in rice for which at least two hand weedings were needed (Mazid et al., 2006). Using herbicide instead of manual weeding $85 \%$ of labour can be saved. Therefore, rice productivity can be improved through the effective use of herbicides by significantly reduce labour. Bhuiyan et al., (2018) reported that weed control efficiency of commonly available herbicide in Bangladesh were more than $80 \%$ and save about $6000-7000$ Taka ha-1 compared to thrice hand weeding. In farmers field, $61 \%$ of the cost was reduced due to herbicide use whereas, $49 \%$ of the cost was reduced when used BRRI weeder + $1 \mathrm{HW}$ for weed management of rice (Table 9).

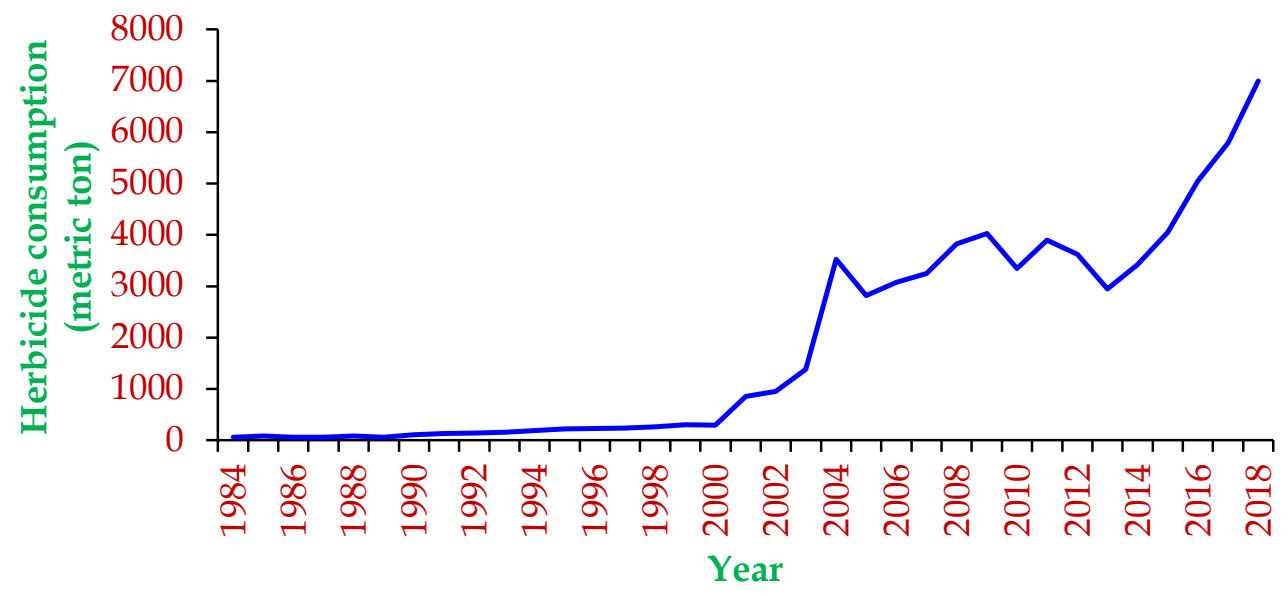

Fig. 2. Herbicide consumption in Bangladesh during 1984 to 2018.

Source: Bhuiyan et al., 2018

Table 9. Weed management cost reduction by using BRRI developed technology in Pirojpur, Gopalganj and Bagerhat district during 2016.

\begin{tabular}{lcccccc}
\hline \multirow{2}{*}{ Weed management treatment } & \multicolumn{2}{c}{ Grain yield $\left(\mathrm{t} \mathrm{ha}^{-1}\right)$} & \multicolumn{2}{c}{ Weed management cost (Tk ha $\left.{ }^{-1}\right)$} & \multicolumn{2}{c}{ Cost reduced over FP } \\
& Aman & Boro & Aman & Boro & Aman & Boro \\
\hline Farmers practice & 4.95 & 6.50 & 12600 & 14400 & - \\
Herbicide fb 1HW & 5.24 & 6.95 & 4750 & 5550 & 62 \\
BRRI weeder fb 1HW & 5.10 & 6.64 & 6450 & 7250 & 49 \\
\hline
\end{tabular}

*fb 1 HW= Followed by 1 hand weeding 
Ecologically sustainable integrated weed management (ESIWM)

Integrated weed control utilizes direct and indirect means for cost-effective weed control or considering economic threshold level (Fig. 3 ). The essential feature of an integrated weed management programme is a critical blend of weed control methods that can be combined economically in a given situation. The contribution of indirect methods on a short and long-term basis and their cost-benefit ratio are needed to be considered for integrated weed management.

For example, increased frequency of plowing and laddering will not completely remove weeds from the crop field. So, a farmer has to employ a direct weeding method for increased production.

Therefore, the frequency of land preparation and laddering should be reduced to a minimum level in which crop establishment is not hampered and then direct weeding should be done in time for reducing crop-weed competition. A high seed rate can not substitute for direct weed control. It is also not economical to add more fertilizer without controlling weeds. Fertilizer efficiency is high when weeds are controlled. Therefore, maximum crop yield at minimum cost should determine the relative choice of integrated weed control. So integrated weed management is the solution.

Some salient features for integrated weed control are given below:

- Crop seed should be free of weed seed. It decreases the severity of weed infestation.

- Weed gets less favourable conditions to grow if the land is prepared well.

- In some cases, a few weeds are found to grow after applying herbicide. It should be controlled by hand or applying postemergence herbicide.

- Use of weeders is friendly to the ecosystem. But one additional hand weeding is required.

- In transplanted rice proper water management reduces the infestation of weed.

- Use of weed competitive variety or allelopathic variety is another option of integrated weed management.

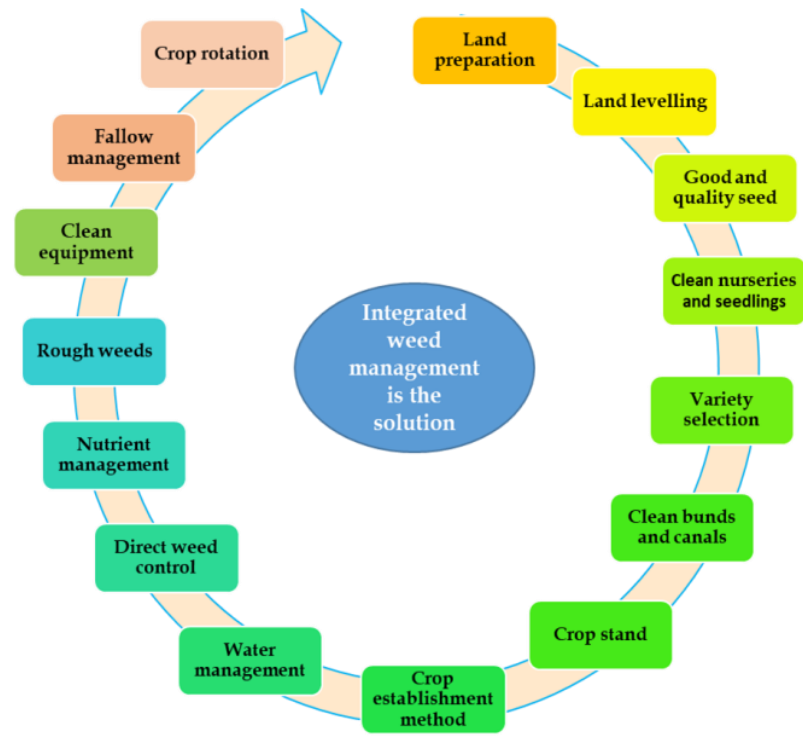

Fig. 3. Integrated weed management in rice production. 
Synthesis of Ecologically sustainable integrated weed management(ESIWM) options

Herbicides remain a simple and cost-effective way to control weeds, as herbicide growth is increasing in Bangladesh, rice productivity can be increased through the judicious and safe use of the herbicide. Non-chemical weed control techniques may become important in the future where environmental safety is a major concern for chemical use. Mechanical weed control should be popularized all over the country where $50 \%$ of weeding cost could be minimized. An integrated weed management system along with other agronomic weed control methods could be followed in the future, e.g., the use of weed competitive variety, bioherbicide allelopathic variety, crop density manipulation, or tillage could be done for ESIWM. Table 10 recapitulate the strengths and weaknesses of the technologies, tools, and highlights for future research needs.

\section{Major issues of weed management to be implemented with related approaches}

The challenge for weed scientists is to develop innovative, effective, economical, and environmentally safe IWM systems that can be integrated into current and future cropping systems to bring a more diverse and integrated approach to weed management. For sustainable and ecologically friendly weed management by 2030 and beyond following major issues and related approaches to be implemented step by step (Table 11).

Table 10. Strength, weakness and research need for integrated weed management.

\begin{tabular}{|c|c|c|c|c|c|}
\hline Method & Technology & Strength & Weakness & Research need & Recommendation \\
\hline $\begin{array}{l}\text { Hand } \\
\text { weeding }\end{array}$ & $\begin{array}{l}\text { Hand } \\
\text { weeding } \\
\text { twice or } \\
\text { thrice }\end{array}$ & $\begin{array}{l}\text { Effective weed control, } \\
\text { Easy }\end{array}$ & $\begin{array}{l}\text { Need more labor } \\
\text { and cost; } \\
\text { Timely weeding } \\
\text { is not done }\end{array}$ & - & $\begin{array}{l}\text { Could be included } \\
\text { in integrated weed } \\
\text { management } \\
\text { (IWM) }\end{array}$ \\
\hline $\begin{array}{l}\text { Mechanical } \\
\text { weed control }\end{array}$ & $\begin{array}{l}\text { BRRI } \\
\text { weeder fb } \\
1 \mathrm{HW}\end{array}$ & $\begin{array}{l}\text { Effective weed control } \\
\text { and reduces hand } \\
\text { weeding and herbicide } \\
\text { use; Reduces labour } \\
\text { cost }\end{array}$ & $\begin{array}{l}\text { Weeder not } \\
\text { available all } \\
\text { over the } \\
\text { country }\end{array}$ & $\begin{array}{l}\text { Massive validation and } \\
\text { demonstration programme } \\
\text { in all upazillas of } \\
\text { Bangladesh }\end{array}$ & $\begin{array}{l}\text { More effective } \\
\text { mechanical weeder } \\
\text { (manual/ power } \\
\text { weeder) needed } \\
\text { Part of IWM }\end{array}$ \\
\hline Herbicide & $\begin{array}{l}\text { Pre or post- } \\
\text { emergence } \\
\text { herbicide fb } \\
\text { 1HW }\end{array}$ & $\begin{array}{l}\text { Effective and timely } \\
\text { weed control. } \\
\text { Saves } 80 \% \text { labor and } \\
\text { time. } \\
\text { Reduces cost of } \\
\text { cultivation }\end{array}$ & $\begin{array}{l}\text { Right herbicide } \\
\text { is not available } \\
\text { in all areas. Safe } \\
\text { use of herbicide } \\
\text { and } \\
\text { environmental } \\
\text { pollution for } \\
\text { chemicals is a } \\
\text { concern }\end{array}$ & $\begin{array}{l}\text { Evaluate new molecule } \\
\text { herbicides and facilitate for } \\
\text { commercial availability } \\
\text { Optimizing dose and time } \\
\text { of application and } \\
\text { elucidating factors affecting } \\
\text { efficiency; } \\
\text { Integrate with other } \\
\text { methods to reduce dose and } \\
\text { increase efficiency; } \\
\text { Long term effect of } \\
\text { herbicides on weed } \\
\text { dynamics, soil microflora, } \\
\text { non-targeted organisms and } \\
\text { herbicide residues in } \\
\text { different crops and } \\
\text { cropping systems }\end{array}$ & $\begin{array}{l}\text { Research } \\
\text { programme } \\
\text { should be } \\
\text { strengthened on } \\
\text { the residual effect } \\
\text { of herbicide and } \\
\text { judicious use of } \\
\text { the herbicide }\end{array}$ \\
\hline Allelopathy & $\begin{array}{l}\text { Allelopathic } \\
\text { variety }\end{array}$ & $\begin{array}{l}\text { Enhances crop } \\
\text { competitiveness }\end{array}$ & $\begin{array}{l}\text { Difficulty in } \\
\text { isolating } \\
\text { allelochemical } \\
\text { compound }\end{array}$ & $\begin{array}{l}\text { Breed cultivars with } \\
\text { allelopathic potential }\end{array}$ & $\begin{array}{l}\text { Part of IWM. } \\
\text { Research work is } \\
\text { ongoing to find } \\
\text { out allelopathic } \\
\text { variety and } \\
\text { allelochemicals }\end{array}$ \\
\hline
\end{tabular}




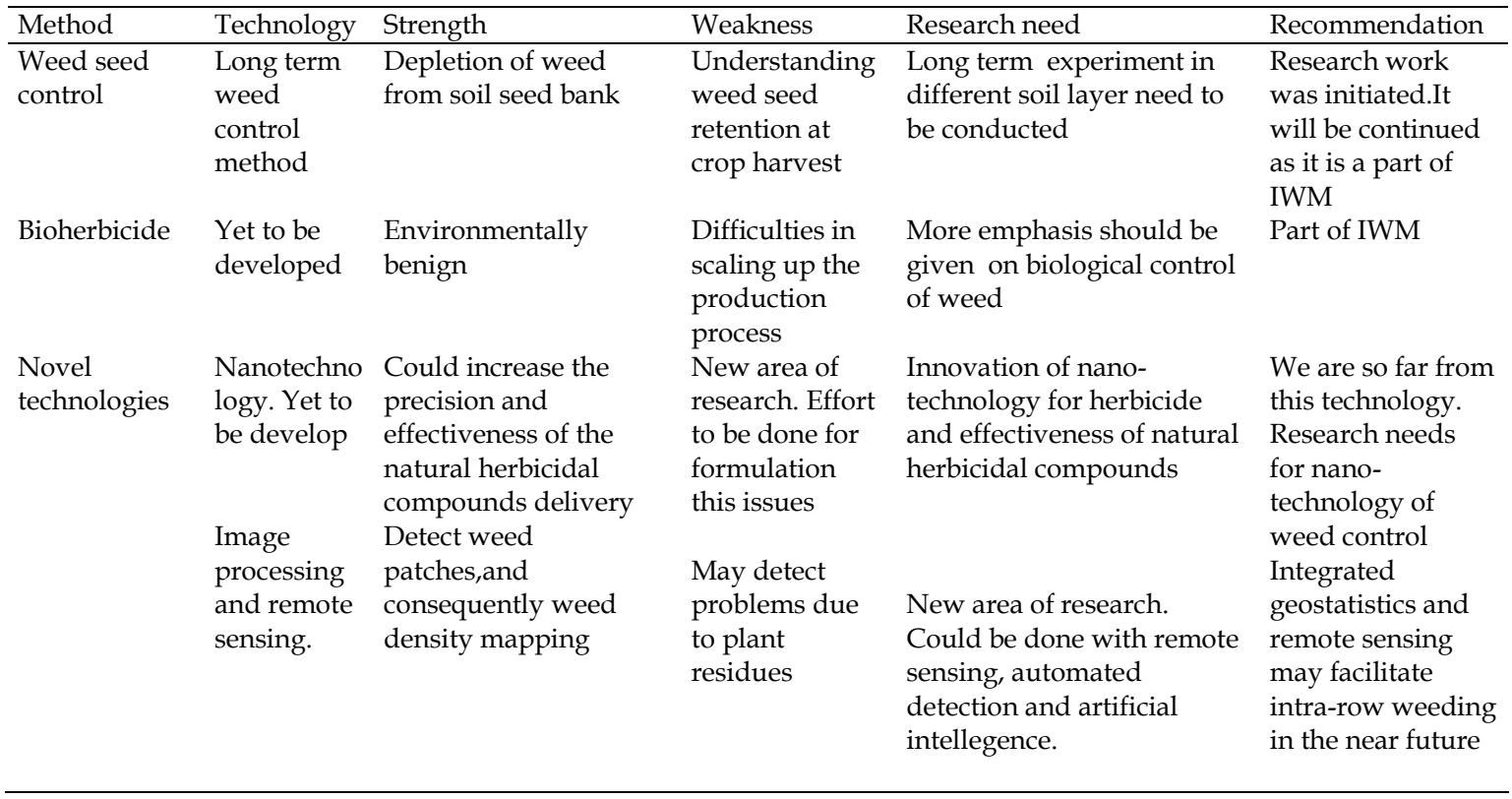

Table 11. Major issues of weed management with connected approaches.

\begin{tabular}{|c|c|}
\hline $\begin{array}{l}\text { Major issue to be } \\
\text { implemented }\end{array}$ & Related approach \\
\hline $\begin{array}{l}\text { Development and } \\
\text { practice ecologically } \\
\text { and sustainable } \\
\text { integrated weed } \\
\text { management }\end{array}$ & $\begin{array}{l}\text { - Develop and disseminate guidelines for incorporating the nonchemical methods } \\
\text { (cultural/mechanical and agronomic manipulation) with chemical methods in the farmers } \\
\text { field } \\
\text { - Reduce herbicide use by employing non-chemical methods } \\
\text { - Develop and disseminate organic weed management practices. } \\
\text { - Use crop residues as mulch material for suppressing weed }\end{array}$ \\
\hline $\begin{array}{l}\text { Managing weeds } \\
\text { through judicious use } \\
\text { of herbicides }\end{array}$ & $\begin{array}{l}\text { - Evaluate new molecule herbicides which is more environmentally sound } \\
\text { - Optimize their time and dose of application and elucidating factors affecting their efficiency } \\
\text { - Integrate with other methods to reduce the dose and increase efficiency. } \\
\text { - Quantify herbicide residue in soil, water and plant parts and consequent entry in the food } \\
\text { chain } \\
\text { - Find out long term effect of herbicides on weed dynamics, soil microflora, non-targeted } \\
\text { organisms and herbicide residues in different crops and cropping systems }\end{array}$ \\
\hline $\begin{array}{l}\text { Facilitating } \\
\text { dissemination of weed } \\
\text { management } \\
\text { technologies, } \\
\text { knowledge and } \\
\text { information }\end{array}$ & $\begin{array}{l}\text { - Conduct training programmes, activities for different stakeholders } \\
\text { - Increase interaction with farmers and stakeholders through direct approaches } \\
\text { - Test and fine-tune of site-specific weed management technologies }\end{array}$ \\
\hline $\begin{array}{l}\text { Developing weed } \\
\text { database in rice }\end{array}$ & $\begin{array}{l}\text { - Create national weed database in different districts in Bangladesh to formulate suitable and } \\
\text { sustainable weed management strategies }\end{array}$ \\
\hline
\end{tabular}


Action plan for three decades on reducing yield loss from rice weeds

To reduce yield loss from weed we have thoroughly discussed available methods of weed management strategies to be implemented. Since herbicide use is increasing due to its effectiveness and cost-effectiveness, so we have to judicially use herbicide. Moreover, not a single method is effective to control weeds in the rice field.

Therefore we have to integrate all methods intelligently. Ecologically sustainable integrated weed management (ESIWM) is the option to manage weeds and to reduce loss from weeds. However, an action plan was developed where all possible weed management options have been addressed.

During the research and development phase (Table 12a, Appendices 2 and 3) cultural, chemical and mechanical weed control will continue with framework development (FWD), yield loss assessment, calibration, and validation of smart management in the specific domain. This work will be followed up and continued.

A number of dissemination and training programme will be done in the farmers' field and concerned agricultural personnel, dealers will be trained regarding herbicide and its safe uses. In the meantime, weed control research with bioherbicide and allelopathic variety will be carried out. As a result, identification of biocontrol agents and allelopathic variety will be identified.

For the period of 2031-2040 and 2041-2050 (Tables 12b, 12c) all possible weed management options will be followed up and continued. If any of the methods will not work it will again go for calibration and validation and this process will continue. Ultimately farmers have to follow integrated weed management with the concerned of environmental issues (Fig. 4). Whatever management is applicable it should be ecologically sound and sustainable.

Table 12. Implementation of ecologically sustainable integrated weed management for the period of 2021-2030, 20312040 and 2041-2050.

a) Period 2021-2030

Ecologically sustainable integrated weed management (ESIWM)

Period: 2021-2030

\begin{tabular}{|c|c|c|c|c|c|c|c|c|}
\hline \multirow{3}{*}{$\begin{array}{l}\text { Weed } \\
\text { management } \\
\text { option }\end{array}$} & \multicolumn{6}{|c|}{ Research and development Phase } & \multicolumn{2}{|c|}{ Dissemination phase } \\
\hline & \multicolumn{2}{|c|}{ Primary } & \multirow{2}{*}{$\begin{array}{l}\text { Intermediate } \\
\text { Mtg - FWK } \\
\end{array}$} & \multicolumn{2}{|l|}{ Maturation } & \multirow{2}{*}{\begin{tabular}{|l} 
Follow up \\
$\mathrm{CO}$ \\
\end{tabular}} & \multirow{2}{*}{\begin{tabular}{|l|} 
Step-1 \\
Train \\
\end{tabular}} & \multirow{2}{*}{\begin{tabular}{|l|} 
Step-2 \\
Demo
\end{tabular}} \\
\hline & III & YL-EST & & Cali-Valid & Sm - Mtg & & & \\
\hline \multicolumn{9}{|l|}{ CWM1 } \\
\hline \multicolumn{9}{|l|}{ CWM2 } \\
\hline \multicolumn{9}{|l|}{ CWM3 } \\
\hline \multicolumn{9}{|l|}{ CWM4 } \\
\hline \multicolumn{9}{|l|}{ CWM5 } \\
\hline \multicolumn{9}{|l|}{ CWM6 } \\
\hline \multicolumn{9}{|l|}{ MWM1 } \\
\hline \multicolumn{9}{|l|}{ MWM2 } \\
\hline \multicolumn{9}{|l|}{ HWM1 } \\
\hline \multicolumn{9}{|l|}{ HWM2 } \\
\hline \multicolumn{9}{|l|}{ HWM3 } \\
\hline \multicolumn{9}{|l|}{ BWM1 } \\
\hline \multicolumn{9}{|l|}{ BWM2 } \\
\hline AWM1 & & & & & & & & \\
\hline
\end{tabular}




\section{b) Period 2031-2040}

Ecologically sustainable integrated weed management (ESIWM)

Period: 2031-2040

Weed management

option

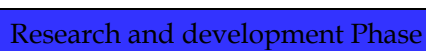

Dissemination phase

III

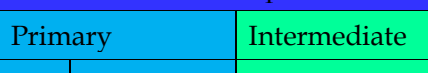

\begin{tabular}{|l|l|l|l|l|}
\hline \multicolumn{2}{|l|}{ Maturation } & Follow up & Step-1 & Step-2 \\
\hline Cali-Valid & Sm-Mtg & CO & Train & Demo \\
\hline & & & & \\
\end{tabular}

\begin{tabular}{|l|l|l|l|} 
& III & YL-EST & Mtg-FWK \\
\hline CWM1 & & & \\
\hline CWM2 & & & \\
\hline CWM3 & & & \\
\hline
\end{tabular}

CWM4

CWM5

CWM6

MWM1

MWM2

HWM1

HWM2

HWM3

BWM1

BWM2

AWM1

\section{c) Period 2041-2050}

Ecologically sustainable integrated weed management (ESIWM)

Period: 2041-2050

Weed management

option

CWM1

CWM2

CWM3

CWM4

CWM5

CWM6

MWM1

MWM2

HWM1

HWM2

HWM3

BWM1

BWM2

AWM1

\section{Bhuiyan et al.}




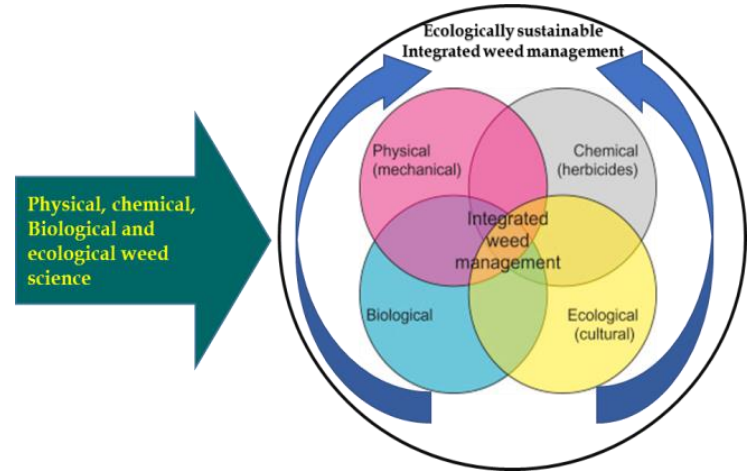

Fig. 4. Ecologically sustainable integrated weed management (Adopted and modified from Merfield CN, 2019).

\section{CONCLUSION}

Hand weeding and chemical weeding are generally very much popular in Bangladesh. Herbicides may now find greater acceptance by the farmers due to higher wages and unavailability of labour. Herbicide producers and weed scientists have an enormous responsibility to educating the farmers and the extension personnel on the judicious and sustainable use of herbicides. The research related to herbicides must go beyond herbicide screening to application techniques, enhancing herbicide efficiency and integrating with ecological methods of weed management. The basic research on weed biology, weed seed bank, bioherbicide, weed ecology and weed control by the tools of remote sensing and geostatistics which has been largely ignored until now needs encouragement. Research on mechanical and biological weed control should get more attention of the researcher to serve the farming community for sustainable food production to achieve sustainable development goals.

\section{RECOMMENDATIONS}

- Developing and upscaling economic and eco-friendly weed management technologies emphasizing mechanical and biological weed control which strengthen the ecologically sustainable integrated weed management (ESIWM) system.

- Non-chemical weed control research should be strengthened. Allelopathic and bioherbicide research may provide nonchemical weed control technology for different crops.

- A nationwide weed survey programme on rice fields and rice based cropping system may be initiated to identify harmful weeds in the climate change situation.

\section{ACKNOWLEDGEMENTS}

The authors wish to thank anonymous reviewers for their suggestions, which significantly improved this article.

\section{AUTHORS' CONTRIBUTION}

MKAB generated idea; MUS and MSK coordinated the research; MKAB developed methodology, provided scientific insights, gathered data, carried out analysis and synthesis, and did the writings for all versions of the manuscript; MUS and MSK performed critical review and editing. All authors read and approved the final manuscript.

\section{DECLARATION OF INTERESTS}

A version of the paper was published in a book "Doubling Rice Productivity in Bangladesh" in 2020 by the Bangladesh Rice Research Institute (BRRI), Gazipur 1701, Bangladesh to commemorate BRRI's 50 th anniversary. The Bangladesh Rice Journal has prior knowledge of the book publication and does not see any conflict of interest.

\section{REFERENCES}

Ahmed, G J U, M A Hassan, A J Mridha, M A Jabbar, C R Riches and E J Z Robinson. 2001. Weed management in intensified lowland rice in Bangladesh. Proc. Brighton Crop Protection Conf -Weeds, BCPC, Farnham, Surrey, UK.

Ahmed S, H Awan, M Salim, and B S Chauhan. 2015. Economics of nitrogen and integrated weed 
management in dry-seeded rice. The J. Animal \& Plant Sci., 25: 1675-1684.

Ahmed, G J U, M K A Bhuiyan, C R Riches, M Mortimer and D Johnson. 2005. Farmers participatory studies of integrated weed management systems for intensified lowland rice. In: $8^{\text {th }}$ biennial agronomy convention, organized by Bangladesh Society of Agronomy, $5^{\text {th }}$ May, Sher-e- Bangla Agricultural University. Dhaka.

IRRI. 2003: Principles of Weed Management. International Rice Research Institute, Philippines. http://www.knowledgebank.irri.org/IPM/WeedMg $\mathrm{mt} /$ default. htm.

BBS. 1991. Yearbook of Agricultural Statistics of Bangladesh. Bangladesh Bureau of Statistics. Ministry of Planning, Govt. of the Peoples Republic of Bangladesh, Dhaka.

BCPA. 2020. Bangladesh crop protection association. https://www.bcpabd.com/pestic ideconsumption.php.

Bhuiyan, M K A. 2016. Effect of resource conservation technologies and weed management on nutrient use efficiency, growth and yield of rice. PhD thesis, Department of Agronomy, Bangladesh Agricultural University, Mymensingh-2202, Bangladesh.

Bhuiyan, M K A, A J Mridha, G J U Ahmed, J A Beguma, R Sultana. 2011. Performance of chemical weed control in direct wet seeded rice culture under two agroecological conditions of Bangladesh. Bangladesh J. Weed Sci., 2 (1 \& 2): 1-8.

Bhuiyan, M K A, M M Mahbub, L Nahar and M Z I Baki. 2017. Effect of nitrogen levels and weed management on yield performance of BRRI hybrid dhan3 under AWD irrigation system. Bangladesh Agron. J., 20 (1): 13-24.

Bhuiyan, M K A, S S Kakon, A A Begum, S K Paul, R R Saha, M A K Mian, M M Islam and M S Hossain. 2018. Weed management in Bangladesh: Present status and future needs. In the $6^{\text {th }}$ conference of weed science society of Bangladesh. 12 May, Bangladesh Rice Research Institute, Gazipur.

Bajwa, A A. 2014. Sustainable weed management in conservation agriculture. Crop protection, 65: 105-113.

BRRI (Bangladesh Rice Research Institute). 2014. Annual report for 2014-15. BRRI, Gazipur 1701, Bangladesh.

BRRI (Bangladesh Rice Research Institute.) 2015-16. Annual report for 2015-16. BRRI, Gazipur 1701, Bangladesh.

BRRI (Bangladesh Rice Research Institute). 2006. Dhaner agacha babostapona (Weed Management of Rice). BRRI, Gazipur-1701, Bangladesh.
BRRI (Bangladesh Rice Research Institute). 1981. Annual Report for 1977-78. BRRI, Gazipur-1701, Bangladesh, pp. 11-19.

Chauhan, B S and S B Abugho. 2013. Weed management in mechanized-sown, zerotill dry seeded rice. Weed Technol., 27: 28-33.

CIMMYT. 2011. Safe use of herbicide and effective weed management course. Written by Corporate Communications on February 2, 2011. Posted in Capacity Building. http://blog.cimmyt.org/safe-useof-herbicide-and-effective-weed-management-cours

De Datta, S K 1981. Principles and practices of rice production. Published by John Wiley \& Sons, Inc. pp. 618.

Galon, L and D Agostinetto 2009. Comparison of empirical models for predicting yield loss of irrigated rice (Oryza sativa) mixed with Echinochloa spp. Crop Prot., 28: 825-830.

Gharde, Y, P K Singha, R P Dubeya and P K Guptab. 2018. Assessment of yield and economic losses in agriculture due to weeds in India. Crop Protection, 107: 12-18.

Hussain, S and A M Aslam. 2008: Weed management in direct-seeded rice. J. Anim. Pl. Sci., 18 (2-3): 86-88.

IRRI (International Rice Research Institute). 2003. Main weeds of rice in Asia. [http://www.knowledgebank.irri.org. Accessed on $1^{\text {st }}$ February 2020.

Islam, A K M S, Mominul, F S Popy, A K Hasan and M P Anwar. 2017. Efficacy and economics of herbicidal weed management in monsoon rice. Bangladesh Journal of Scientific Agriculture, 1: 275-293.

Islam, A K M S, M T Islam, M Sh Islam, L Rahman and M A Rahman 2017. Performance Evaluation of BRRI Power Weeder for Low Land Rice (Oryza sativa L.) Cultivation. The Agriculturists, 15 (1): 40-48.

Kabir, M S, M U Salam, A Chowdhury, N M F Rahman, K Iftekharuddaula, M Rahman, M Rashid, S Dipti, A Islam, M Latif, A Islam, M Hossain, B Nessa, T Ansari, M Ali and J K Biswas 2015. Rice Vision for Bangladesh: 2050 and Beyond. Bangladesh Rice Journal, 19 (2): 1-18. https://doi.org/10.3329/brj.v19i2.28160.

Kabir, M S, M U Salam, A K M S Islam, M A R Sarkar, M A A Mamun, M C Rahman, B Nessa, M J Kabir, H B Shozib, M B Hossain, A Chowdhury, M Nasim, K M Iftekharuddaula, M S Hossain, M K A Bhuiyan, B Karmakar, MS Rahman, M M Haque, M T Khatun, M P Ali, S M H A Rabbi, P L Biswas, E S M H Rashid and N M F Rahman. 2020. Doubling rice productivity in Bangladesh: A way to achieving SDG 2 and moving forward. Bangladesh Rice Journal, 24 (2) : $1-47$. 
Karim, R S M, A B Man and I B Sahid. 2004. Weed problems and their management in rice fields of Malaysia: an overview. Weed Biol. Manage, 4: 177-186.

Kathirvelan, P, and V Vaiyapuri .2003. Relative efficacy of herbicides in transplanted rice. Indian J. Weed Sci., 35:257-258.

Khaliq, A, A Matloob, H M Shafique, Z A Cheema, and A Wahid. 2011. Evaluating sequential application of pre- and post-emergence herbicides in dry seeded fine rice. Pak. J. Weed Sci. Res., 17: 111-123.

Kim, S C and W G Ha. 2005. Direct-seeding and weed management in Korea. In: K Toriyama, K L Heong, B Hardy, (Eds.), Rice Is Life: Scientific Perspectives for the 21st Century. International Rice Research Institute, and Tsukuba (Japan): Japan International Research Center for Agricultural Sciences, Los Banos (Philippines), pp. 181 - 184. Proceedings of the World Rice Research Conference held in Tokyo and Tsukuba, Japan, 4-7 November 2004.

Liebman M and E R Gallandt. 1997. Many little hammers: ecological management of crop weed interactions. In: Jackson. LE (Ed.). Ecology in Agriculture. Academic Press, San Diego, CA, USA, pp. 291-343.

Mahbub M M, and M K A Bhuiyan. 2019. Performance of Quinclorac+ Fenoxaprop-P-Ethyl+ PyrazosulfuronEthyl 70\% WP against Annual Weeds of Transplanted Rice. American-Eurasian J. Agric. $\mathcal{E}$ Environ. Sci., 19 (6): 439. DOI: 10.5829/id osi.aejaes.2019.439.447

Mamun, A A. 1990. Weeds and their control: A review of weed research in Bangladesh. Agricultural and Rural Development in Bangladesh. Japan Intl. Co-operation agency. Dhaka, Bangladesh. JSARD. Pub. No. 19. pp. $45-72$.

Marambe, B. 2009. Weedy rice - evolution, threats and management. Trop. Agriculturist., 157: 43-64.

Marambe, B. R Punyawardena, P Silva, S Premalal, V Rathnabharathie, B Kekulandala, U Nidumolu and M Howden. 2015. Climate, climate risk, and food security in Sri Lanka: Need for strengthening adaptation strategies (1959-1789). In: W. Leal (Ed.). Handbook of climate change adaptation. Springer Verlag, Berlin, Heidelberg.

Mazid, M A, M A Jabber, C R Riches, E J Z Robinson, M Mortimer and L J Wade. 2001. Weed management implications of introducing dry-seeded rice in the Barind Tract of Bangladesh. Proceedings of the BCPC Conference-Weeds. Farnham (UK): British Crop Protection Council. pp. 211-216

Mazid, M A, C R Riches, A M Mortimer, L J Wade and D E Johnson. 2006. Improving rice-based cropping systems in north-west Bangladesh. Proceedings of the Fifteenth Australian Weeds Conference. September 24-28, Adelaide, South Australia.

Mazid, M A, M A Jabber, C R Riches, E J Z Robinson, M Mortimer and L J Wade. 2001. Weed management implications of introducing dry-seeded rice in the Barind Tract of Bangladesh. Proceedings of the BCPC Conference-Weeds. Farnham (UK): British Crop Protection Council. pp. 211-216.

Menalled, F D. 2018. Sustainable agriculture and integrated weed management. In: Korres, $\mathrm{N} \mathrm{E}$, Burgos, N R, Duke, S O. (Eds.), Weed Control. Sustainability, Hazards and Risks in Cropping Systems Worldwide.

Merfield, C.N. 2019. Chapter 5. Integrated weed management in organic farming . Woodhead publishing · pp. 117-180.

Milberg, P and E Hallgren. 2004. Yield loss due to weeds in cereals and its large-scale variability in Sweden. Field Crop. Res., 86: 199-209.

Oerke, E C and H W Dehne. 1997. Global crop production and the efficacy of crop protection - current situation and future trends. Eur.J. Plant Pathol., 103: 203-215.

Oerke, E C and H W Dehne. 2004. Safeguarding production losses in major crops and the role of crop protection. Crop Prot., 23: 275-285.

Pandey, S. 2009. Effect of weed control methods on rice cultivars under the system of rice intensification (SRI). MSc (Agronomy) Thesis. Tribhuvan Univ. Institute of Agriculture and Animal Science, Rampur, Chitwan, Nepal.

Rammohan, J, A L Narayanan, R Poonguzhalan, R Mohan, and A Mohamed Hanifa. 2009. Efficacy of Pre-emergence Herbicides for Weed Control in Lowland Transplanted Rice in the Coastal Saline Soils. Indian journal of weed science, 31 (3 \& 4): 142-144.

Ranjit, J D, K P Bhurer, K P Koirala, Y Thakur and D N Chaudhary. 1989. Screening of herbicides in upland and transplanted rice (129-142). In: Proc. 14th Summer Crop Workshop, NRIP, Parwanipur, Nepal.

Rao, A N and K Moody. 1994. Ecology and Management of Weeds in Farmers' Directseeded Rice (Oryza Sativa L.) Fields. International Rice Research Institute, Los Banos, Philippines.

Rashid, M H, A M Murshedul, A N Rao and J K Ladha. 2012. Comparative efficacy of pretilachlor and hand weeding in managing weeds and improving the productivity and net income of wet-seeded rice in Bangladesh. Field Crops Research, 128: 17-26. 
Sarker, M Y. 1996. Weed infestation and crop performance in Aus rice as affected by planting and weeding regime. M.S. Thesis, Department of Agronomy, Bangladesh Agril. Univ., Mymensingh, pp. 31-84.

Singh, Y, V P Singh, G Singh, D S Yadav, R K P Sinha, D E Johnson and A M Mortimer. 2011. The implications of land preparation, crop establishment method and weed management on rice yield variation in the ricewheat system in the Indo-Gangetic plains. Field Crops Res., 121: 6474.

Singh, S R, S Chhokar, R Gopal, J K Ladha, R K Gupta, V Kumar and M Singh .2007. Integrated weed management. A key to success for direct seeded rice in the Indo-Gangetic Plains (261-270). Integrated crop and resource management in the rice - Wheat system of South Asia. IRRI, Philippines.

Strek, H J. 2014. Herbicide resistance. What have we learned from other disciplines? J. Chem. Biol., 7: 129132.

Soltani, N, J A Dille, I C Burke, W J Everman, M J VanGessel, V M Davis and P H Sikkema. 2016. Potential corn yield losses from weeds in North America. Weed Technol., 30: 979-984.

Sondhia Shobha. 2014. Herbicides residues in soil, water, plants and non-targeted organisms and human health implications: an Indian perspective. Indian Journal of Weed Science 46 (1): 66-85

Travlos, I S. 2013. Competition between ACC-inhibitor resistant and susceptible sterile wild oat (Avena sterilis L.) biotypes. Weed Sci., 61: 26-31.

Walker, P T. 1983. Crop losses: the need to quantify the effects of pests, diseases and weeds on agricultural production. Agric. Ecosyst. Environ., 9: 119-158.

Weaver, S E, and J A Ivany. 1998. Economic thresholds for wild radish, wild oat, hempnettle and corn spurry in spring barley. Can. J. Plant Sci., 78: 357-361.

Young, S L, S K Pitla, F K Van Evert, J K Schueller and F J Pierce. 2017. Moving integrated weed management from low level to a truly integrated and highly specific weed management system using advanced technologies. Weed Res., 57: 1-5.

Zanin, G, A Berti, M Giannini. 1992. Economics of herbicide use on arable crops in North-Central Italy. Crop Prot., 11: 174-180.

Zhao, D L, G N Atlin, L Bastiaans and J H J Spiertz. 2006. Cultivar-weed competitiveness in aerobic rice: heritability, correlated traits, and the potential for indirect selection in weed-free environment. Crop Sci., 46: 372-38.

\section{Acronyms and Abbreviations}

BRRI= Bangladesh Rice Research Institute

IWM= Integrated Weed Management

BINA= Bangladesh Institute of Nuclear Agriculture

IRRI= International Rice Research Institute

$\mathrm{GO}=$ Government organization

IPM = Integrated pest management

$\mathrm{NGO}=$ Non-government organization

SDG $=$ Sustainable development goal

CIMMYT= The International Maize and Wheat Improvement Center

$\mathrm{G}=$ Granular formulation

DAS= Days after sowing

$\mathrm{DAT}=$ Days after transplanting

$\mathrm{DAP}=$ Days after planting

$\mathrm{SDR}=$ Sum Dominance Ratio

$\mathrm{FB}=$ Followed by

$\mathrm{AI}=$ active ingredient

$\mathrm{EC}=$ Emulsifiable concentrate

$\mathrm{SC}=$ Soluble concentrate

$\mathrm{BPW}=\mathrm{BRRI}$ power weeder

$\mathrm{BW}=\mathrm{BRRI}$ weeder

$\mathrm{HW}=$ Hand weeding

BBS= Bangladesh Bureau of Statistics

DAHA = Days after herbicide application

ESIWM= Ecologically sustainable integrated weed management 
Appendix 1a. Photograph of low land weeds commonly found in rice field.

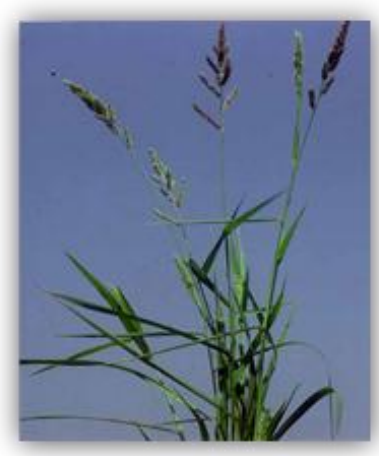

Echinochloa crus-galli

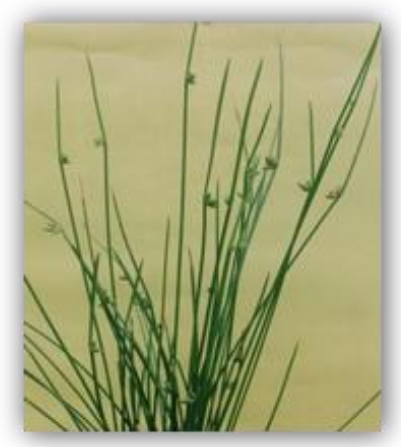

Scirpus maritimus

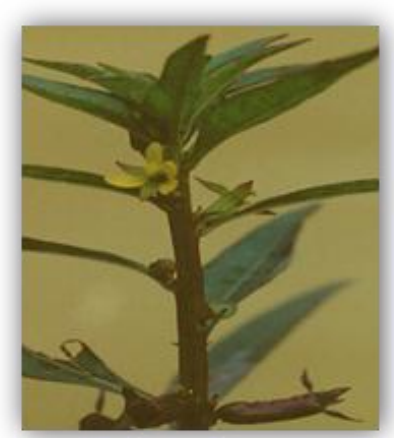

Ludurigia octovalvis

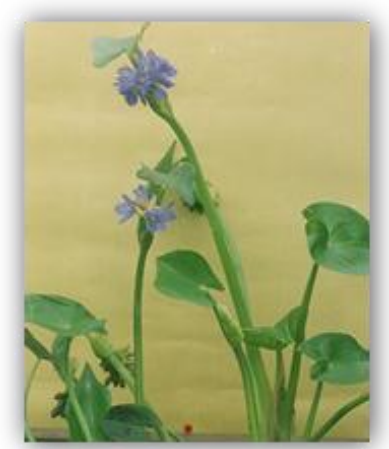

Monochoria vagianalis

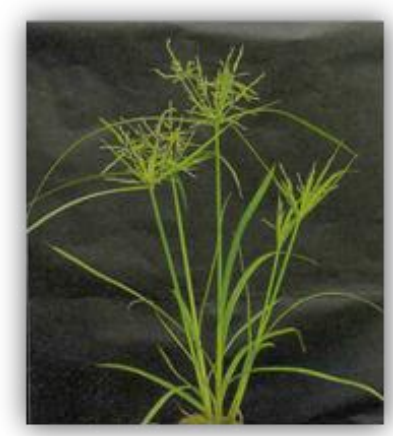

Cyperus iria

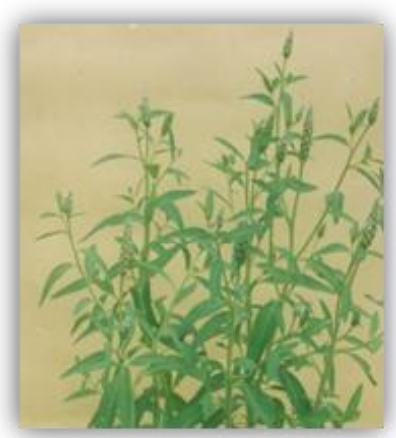

Sphenoclea zeylanica

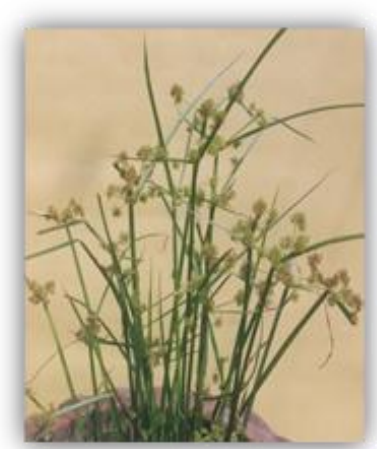

Cyperus difformis

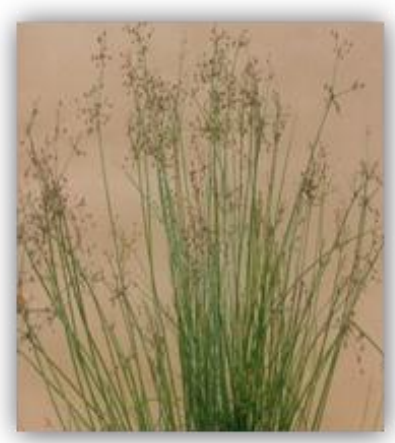

Fimbristylis miliacea

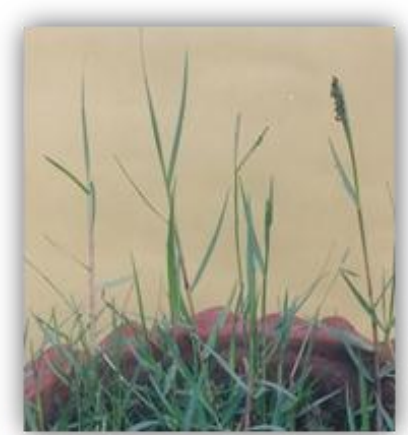

Paspalum distichum 
Appendix 1b. Photograph of up land weeds commonly found in rice field.

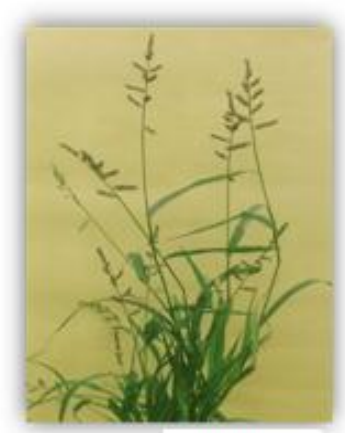

Echinochloa colona

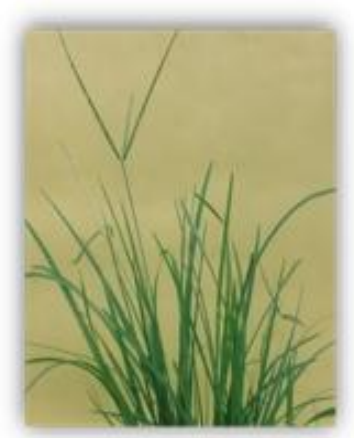

Elusine indicn

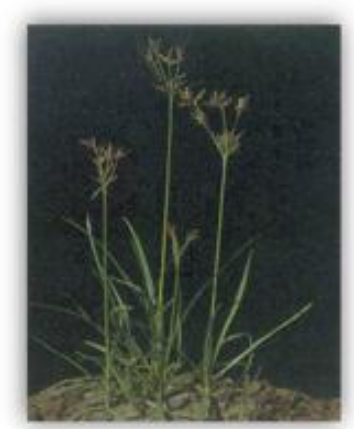

Cyperus rotundus

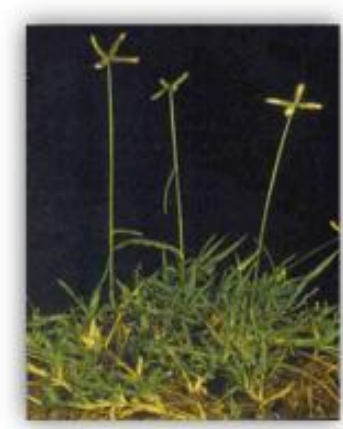

Dactyloctenium negyptium

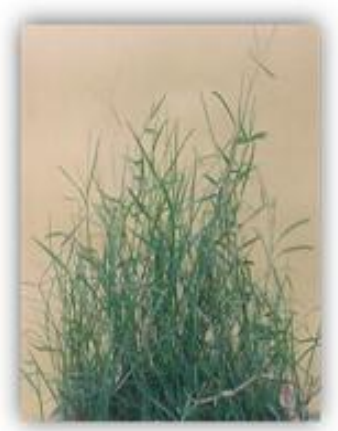

Cynodon dactylon

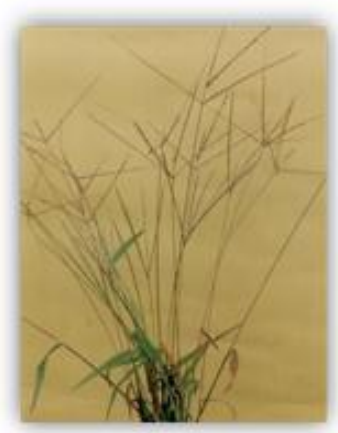

Digitarin sanguinalis

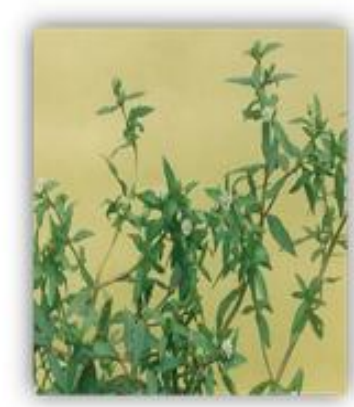

Eclipta allba

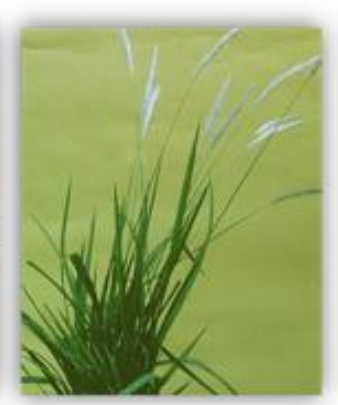

Imperata cylindrica

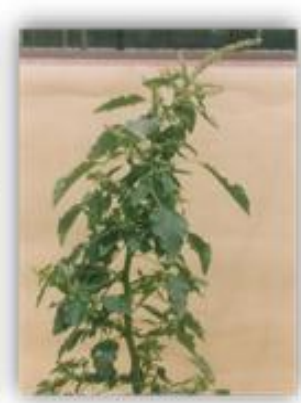

Amuranthus spinosus

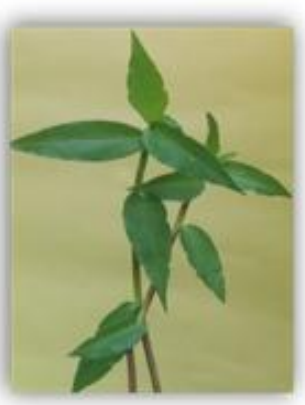

Commelina diffusa 
Appendix 2. Weed management at a glance with abbreviation.

\begin{tabular}{lll}
\hline $\begin{array}{l}\text { Broad weed } \\
\text { management }\end{array}$ & Weed management option & Abbreviation \\
\hline Cultural & i. Fallow management & CWM1 \\
& ii. Good land preparation \& Stale seedbed technique & CWM2 \\
& iii. Planting method and plant population & CWM3 \\
& iv. Crop rotation & CWM4 \\
& v. Water mgt- Flooding & CWM5 \\
& vi. Weed competitive variety & CWM6 \\
Physical & i. Manual weeding & MWM1 \\
& ii. Mechanical weeding & MWM2 \\
Chemical & i. Pre emergence herbicide & HWM1 \\
& ii. Post emergence herbicide & HWM2 \\
Biological & iii. Pre plant herbicide & HWM3 \\
& i. Rice duck culture & BWM1 \\
Biochemical & ii. Bioherbicide & BWM2 \\
\hline
\end{tabular}

Note: $\mathrm{CWM}=$ Cultural weed management; $\mathrm{MWM}=$ Mechanical weed management; HWM= Herbicide weed management; $\mathrm{BWM}=$ Biological weed management; $\mathrm{AWM}=$ Allelophathic weed management

Appendix 3. Some abbreviation with elaboration in relation to Tables 12a, 12b and 12c.

\begin{tabular}{|l|l|l|l|}
\hline Programme & Phase & Abbreviation & Elaboration \\
\hline \multirow{4}{*}{$\begin{array}{l}\text { Research and } \\
\text { Development }\end{array}$} & Primary & III & Identification, isolation and innoculation \\
\cline { 2 - 4 } & & YL-EST & Yield loss estimation \\
\cline { 2 - 4 } & Intermediate & Mtg-FWK & Management framework \\
\cline { 2 - 4 } & Maturation & Cali-Valid & Calibration and validation \\
\cline { 2 - 4 } & Sm-Mtg & Smart management \\
\cline { 2 - 4 } & Follow up & CO & Continuous obervation \\
\hline \multirow{2}{*}{ Dissemination } & Step-1 & Train & Training \\
\cline { 2 - 4 } & Step-2 & Demo & Demonstration \\
\hline
\end{tabular}


160 Bhuiyan et al. 